\title{
10. COMPOSITION AND ORIGIN OF MARINE ASH LAYERS AND EPICLASTIC ROCKS FROM THE KERGUELEN PLATEAU, SOUTHERN INDIAN OCEAN (LEGS 119 AND 120) ${ }^{1}$
}

\author{
Peter Rene Bitschene, ${ }^{2,3}$ Klaus Wilhelm Mehl2,4 and Hans-Ulrich Schmincke ${ }^{2,4}$
}

\begin{abstract}
Epiclastic volcanogenic rocks recovered from the Kerguelen Plateau during Ocean Drilling Program Legs 119 and 120 comprise (pre-)Cenomanian(?) claystones ( $52 \mathrm{~m}$ thick, Site 750 ); a Turonian(?) basaltic pebble conglomerate (1.2 $\mathrm{m}$ thick, Site 748; Danian mass flows (45 m thick, Site 747); and volcanogenic debris flows of Quaternary age at Site 736 (clastic apron of Kerguelen Island). Pyroclastic rocks comprise numerous Oligocene to Quaternary marine ash layers.

The epiclastic sediments with transitional mid-ocean-ridge basalt (T-MORB) origin indicate weathering (Site 750) and erosion (Site 747) of Early Cretaceous T-MORB from a then-emergent Kerguelen Plateau, connected to Late Cretaceous tectonic events. The basal pebble conglomerate of Site 748 has an oceanic-island basalt (OIB) composition and denotes erosion and reworking of seamount to oceanic-island-type volcanic sources.

The vitric- to crystal-rich marine ash layers are a few centimeters thick, have rather uniform grain sizes around $60 \pm 40 \mu \mathrm{m}$, and are a result of Plinian eruptions. Crystal-poor silicic vitric ashes may also represent co-ignimbrite ashes. The ash layers have bimodal, basaltic, and silicic compositions with a few intermediate shards. The basaltic ashes are evolved high-titanium T-MORB; a few grains in a silicic pumice lapilli layer have a low-titanium basaltic composition. The silicic ashes comprise trachytic and rhyolitic glass shards belonging to a high-K series, except for a few low-K glasses admixed to a basaltic ash layer.

Feldspar and clinopyroxene compositions fit the glass chemistry: high-Ti tholeiite-basaltic glasses have plagioclase of $\mathrm{An}_{40-80}$ and pigeonite to augite clinopyroxene compositions. Silicic ashes have K-rich anorthoclase and minor plagioclase around $\mathrm{An}_{20}$ and ferriaugitic to hedenbergitic clinopyroxene compositions. The line of magmatic evolution for the glass shards is not compatible with simple two-end member (high-Ti T-MORB and high-K rhyolite) mixing, but favors successive $\mathrm{Ca}-\mathrm{Mg}$-Fe pyroxene, $\mathrm{Ti}$ magnetite, and apatite fractionation, and $\mathrm{K}$-rich alkali feldspar fractionation in trachytic magmas to yield rhyolitic compositions. Plagioclase fractionation occurs throughout. This qualitative model is in basic accordance with the observed mineral assemblage. However, as the time span for explosive volcanism spans $>30$ m.y., this basic model cannot comply with fractional crystallization in a single magma reservoir.

The ash layers resulted from highly explosive eruptions on Kerguelen and, with less probability, Heard islands since the Oligocene. The explosive history starts with widespread Oligocene basaltic ash layers that indicate sea-level or subaerial volcanism on the Northern Kerguelen Plateau. After a hiatus of 24 m.y.(?), explosive magmatic activity was vigorously renewed in the late Miocene with more silicic eruptions. A peak in explosive activity is inferred for the Pliocene-Pleistocene.

The composition and evolution of Kerguelen Plateau ash layers resemble those from other hotspot-induced, oceanic-island realms such as Iceland and Jan Mayen in the North Atlantic, and the Canary Islands archipelago in the Central Atlantic.
\end{abstract}

\section{INTRODUCTION}

Ocean Drilling Program (ODP) Legs 119 and 120 were designed to drill a latitudinal transect across the submarine Kerguelen Plateau (Fig. 1) from Kerguelen Island $\left(49^{\circ} \mathrm{S}\right)$ to Prydz Bay $\left(68^{\circ} \mathrm{S}\right)$. Our major objectives in this area were (1) to determine the composition and structure of the Kerguelen Plateau basement (Plateau evolution; Mehl et al., 1991), and (2) to discover the volcanotectonic evolution after the cessation of plateau volcanism and during oceanic-island growth and destruction on the Kerguelen Plateau (seamount evolution; this study).

The plateau-building stage (Bitschene et al., 1989a; Mehl et al., 1991) of the Kerguelen Plateau is characterized by Early

\footnotetext{
${ }^{1}$ Wise, S. W., Jr., Schlich, R., et al., 1992. Proc. ODP, Sci. Results, 120: College Station, TX (Ocean Drilling Program).

2 Institut für Mineralogie, Ruhr Universität Bochum, D-4630 Bochum, Federal Republic of Germany.

${ }^{3}$ Present address: Departamento Geologia/Laboratorio Bioestratigrafia, Universidad Nacional de la Patagonia San Juan Bosco, Ciudad Universitaria $\mathrm{Km} \mathrm{4,} 9000$ Comodoro Rivadavia, Argentina.

${ }^{4}$ Present address: Forschungszentrum für marine Geowissenschaften der Christian-Albrechts-Universität zu Kiel, Wischhofstraße 1-3, D-2300 Kiel 14, Federal Republic of Germany.
}

Cretaceous (oceanic?) flood basalt volcanism. The basalts dredged from the seafloor and drilled during Legs 119 and 120 are tholeiitic T-MORB (Bassias et al., 1987; Leg 119: Alibert, 1991, and Mehl et al., 1991; Leg 120: Schlich, Wise, et al., 1989 ) with a characteristic light rare earth element (LREE) enrichment (e.g., Site 738 basalts with $[\mathrm{Ce} / \mathrm{Yb}]_{\mathrm{cn}}=3.2-4.1$ ) and intermediate $\mathrm{Zr} / \mathrm{Nb}$ ratios $(15 \pm 5$; Schlich, Wise, et al., 1989; Mehl et al., 1991). A DUPAL (Hart, 1984) isotope signature is common to all Kerguelen Plateau basalts (e.g., Storey et al., 1989, and literature cited therein; Alibert, 1991). So far, there is no evidence for direct contamination of the Kerguelen Plateau lithosphere with continental crust. Trace element and isotope compositions and ratios of Kerguelen Plateau T-MORB are best explained by interaction of the long-lived asthenospheric Kerguelen hotspot ( $>120 \mathrm{Ma}$ ) with the oceanic lithosphere, and a third component, responsible for DUPAL isotope and trace element patterns, may be recycled (oceanic?) crust (Mehl et al., 1991).

Extensive tholeiitic T-MORB flood basalt volcanism on the Kerguelen Plateau was confined to the Mesozoic, subaerial to shallow-marine plateau stage. Oceanic-island/seamount-type alkali-basaltic and trachytic to alkali-rhyolitic volcanism, however, was active during the Cretaceous (Site 748), Tertiary, and 


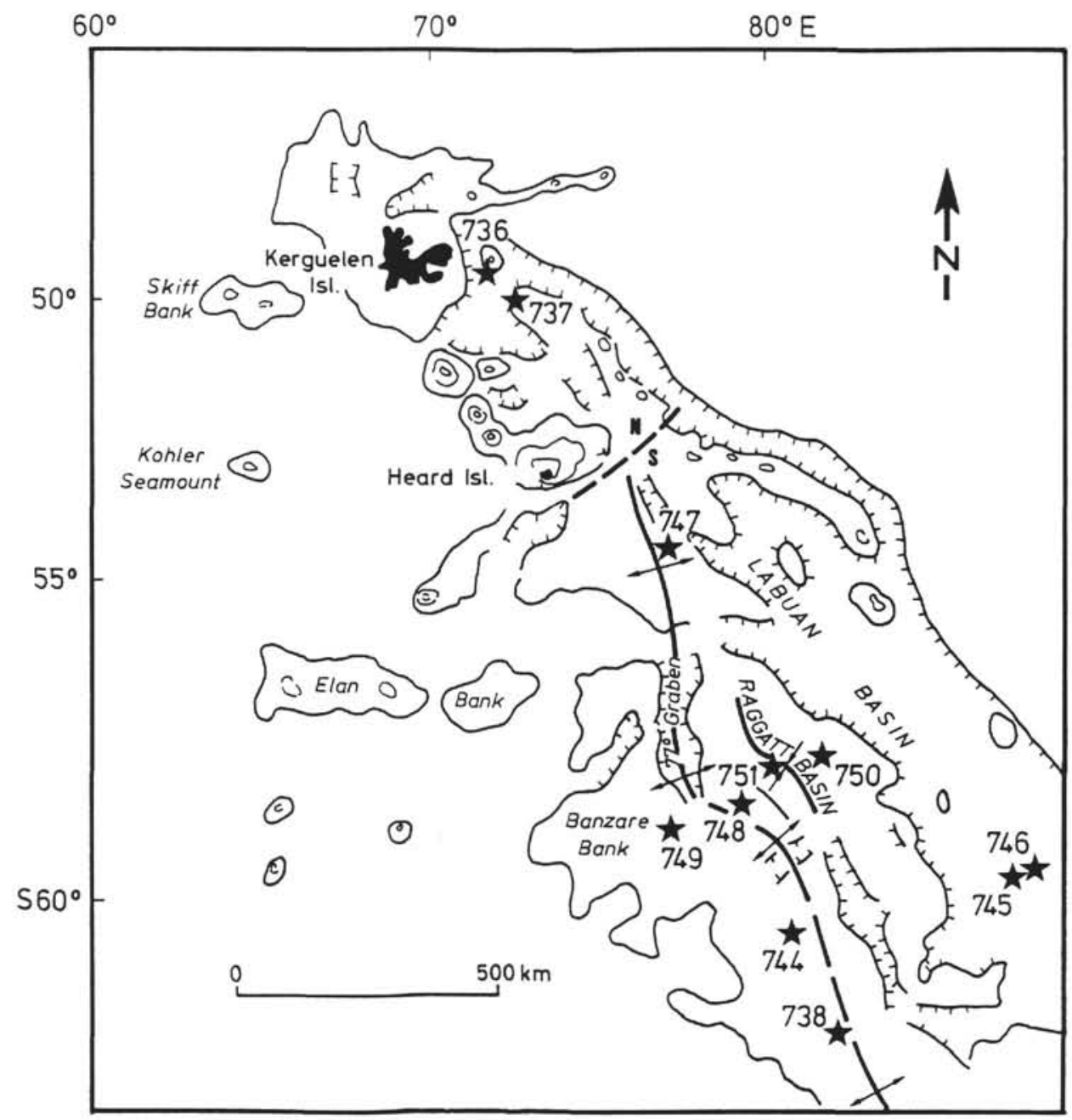

Figure 1. Morphotectonic map of the Kerguelen Plateau with locations of sites drilled during Legs 119 and 120 .

Quaternary (Heard and Kerguelen islands). Thetholeiitic plateau stage and the subsequent alkali-basaltic seamount evolution on the Kerguelen Plateau were accompanied and followed by tectonic movements, which culminated in the final breakup of the Broken Ridge from the Northern Kerguelen Plateau at about 45-42 Ma (Munschy and Schlich, 1987).

The plateau-building stage, seamount evolution, and transitional and rifting episodes, all left their distinct volcaniclastic imprints in the lithostratigraphy of the Kerguelen Plateau. This paper deals with the composition, modes of transport and emplacement, and magmatic evolution of volcaniclastic rocks drilled at Sites 736, 737, 745, 747, 748, 750, and 751 (Figs. 1 and 2). Emphasis is on the composition and significance of ash layers with respect to seamount evolution.

\section{METHODS}

We studied 35 thin sections microscopically. Of these, 20 polished thin sections were analyzed by electron microprobe (EMP), using a fully automated Camebax wavelength-dispersive system (Cameca). Operating conditions were as follows: $15-\mathrm{kV}$ accelerating voltage, 14-nA beam current for primary minerals, and 8-nA for zeolites and glasses; 20 -s counting time; and a beam diameter of $6-8 \mu \mathrm{m}$. Sodium and potassium were measured first to minimize loss of these light elements due to volatilization. We suspect that $\mathrm{Na}$ loss in silicic glasses is still in the range of $0.5 \%-1.5 \%$.

Bulk-rock chemical analyses were conducted by X-ray fluorescence (XRF) on glass fusion beads, using a fully automated Phillips PW 1400 spectrometer. Each bead was formed from a $1: 4$ mixture of rock powder, dried at $110^{\circ} \mathrm{C}$ for $24 \mathrm{hr}$, and flux (lithium metaborate and dilithium tetraborate [Spectromelt, Merck AR]) melted at $1000^{\circ} \mathrm{C}$ for $20 \mathrm{~min}$ and poured into a $34-\mathrm{mm}$-diameter pellet mold.

$\mathrm{Fe}^{2+}$ was determined by semiautomatic potentiometric titration of the hydrofluoric acid-silver perchlorate digested sample, with standard potassium bromide solution. $\mathrm{CO}_{2}$ was determined by closed-system coulometric titration of barium perchlorate solution, into which the gases were led after heating the sample in a tube furnace at $1280^{\circ} \mathrm{C} . \mathrm{H}_{2} \mathrm{O}^{+}$was measured by closed-system coulometric titration of a nonaqueous Karl Fischer reagent into which the carrier gas $\left(\mathrm{N}_{2}\right)$ was passed, containing water stripped from the sample by heating it in a Pt-crucible to $1300^{\circ} \mathrm{C}$ with an induction furnace.

All graphs and interpretations on the chemistry of volcanic glasses are based on normalized, water- and carbonate-free analyses. Values given in the text are measured concentrations. 


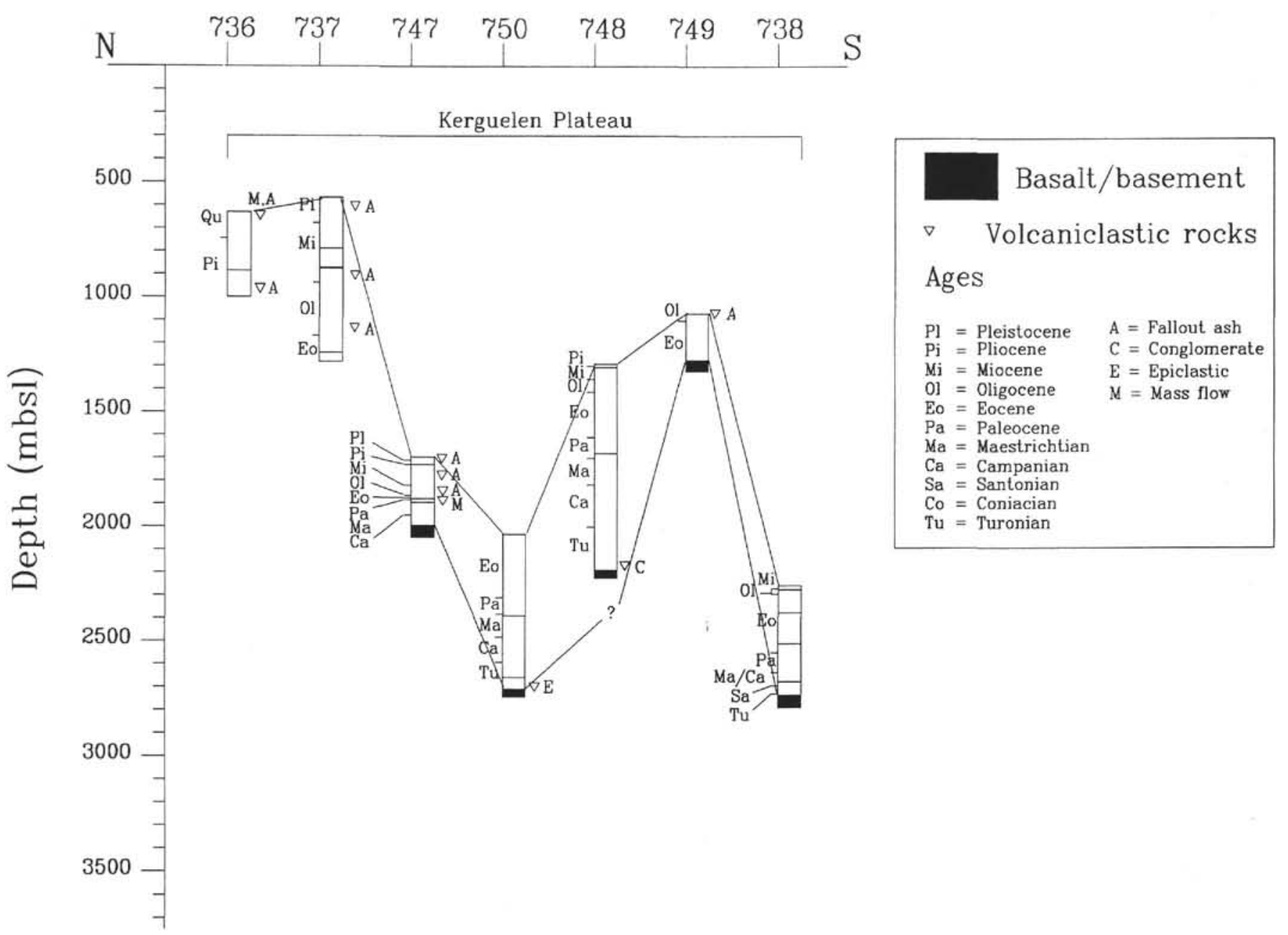

Figure 2. Stratigraphic position and relative geographic and depth position of volcaniclastic layers drilled during Legs 119 and 120 .

\section{RESULTS \\ Classification and Stratigraphic Position}

In general, volcaniclastic rocks comprise all clastic volcanic materials formed by any process of fragmentation, and dispersed and deposited by any transportation and sedimentation process. They may be divided into (1) pyroclastic rocks derived directly from explosive volcanism, and (2) epiclastic rocks formed by weathering, erosion, and redeposition of volcanic rocks. Abundant fresh glass particles and good sorting are strong indicators for pyroclastic fallout. Marine fallout ash layers are distinguished by color, thickness in the centimeter range, abundance of vitric shards, good sorting, and wide areal dispersion around the source volcanoes (Bitschene and Schmincke, 1990). The Kerguelen Plateau volcaniclastic rocks investigated here were divided into (1) marine fallout ash and lapilli layers, or fallout tephra layers, and (2) epiclastic deposits.

Five upper Oligocene ash layers, two upper Miocene ash layers, and four Pliocene ash layers were found at Site 737 on the Northern Kerguelen Plateau. We recovered two Oligocene layers, one Miocene, and three Pliocene-Pleistocene layers at Site 747; only two Pliocene-Pleistocene layers were found at Site 745 (Fig. 2 and Table 1).
Sand- to silt-size volcaniclastic detritus, however, is admixed throughout the Eocene to Holocene marine sequences. Olive-gray to black, basaltic volcanic ash and sand is common in the Pliocene to Quaternary sediments at Site 736, the closest site to Kerguelen Island (about $130 \mathrm{~km}$ southeast). Site 737 has disseminated volcanic ash above the Eocene, peaking in the middle to upper Miocene. The 1.5-m-thick Quaternary diatom ooze at the top of this sequence is rich in volcanic ash and lapilli.

A varicolored volcaniclastic unit was drilled at Site 747 (Fig. 2) in Hole 747A (Sections 120-747A-20X-2, $45 \mathrm{~cm}$, to $-21 \mathrm{X}-1,2 \mathrm{~cm}$ ), and in Hole $747 \mathrm{C}$ (Sections 120-747C-3R-3, 49 $\mathrm{cm}$, to $-5 \mathrm{R}-\mathrm{CC})$. Drilling recovered only $7.6 \mathrm{~m}$ of this volcaniclastic unit at Hole $747 \mathrm{~A}$, and $25.6 \mathrm{~m}$ at Hole $747 \mathrm{C}$. Logging results from Hole $747 \mathrm{C}$, however, indicate $45 \mathrm{~m}$ of thickness and allow us to divide the volcaniclastic sequence into three successively thickening units (Schlich, Wise, et al., 1989). A cobble conglomerate at Site 748 is $1.2 \mathrm{~m}$ thick (Sections $120-748-79 \mathrm{R}-4,58 \mathrm{~cm}$, to $-79 \mathrm{R}-5,25 \mathrm{~cm}$ ) and represents the basal part of a unique, 500 -m-thick, Cr-rich glauconitic sequence (Bitschene et al., this volume). A 52-m-thick, clayey to sandy, epiclastic sequence, only $7.7 \mathrm{~m}$ of which was recovered, was drilled at Hole $750 \mathrm{~B}$ (Section 120-750B-12W to $-14 \mathrm{R}-1,23 \mathrm{~cm}$ ). This volcanogenic epiclastic sequence (Fig. 
Table 1. Interval, type, composition, and approximate age of the volcaniclastic sediments.

\begin{tabular}{|c|c|c|c|c|}
\hline $\begin{array}{l}\text { Core, section. } \\
\text { interval }(\mathrm{cm})\end{array}$ & Type & Composition & Age (Ma) & Code \\
\hline \multicolumn{5}{|l|}{$119-736 \mathrm{~A}-$} \\
\hline $3 \mathrm{H}-1,130-132$ & Ash layer & Trachytic & 0.4 & LI \\
\hline $3 \mathrm{H}-2,24-26$ & Ash layer & Trachytic & 0.4 & L.2 \\
\hline $6 \mathrm{H}-1,44-46$ & Ash layer & Bimodal & 0.7 & L.3 \\
\hline $7 \mathrm{H}-1,10-12$ & Ash layer & Bimodal & 0.8 & L4 \\
\hline $7 \mathrm{H}-1.34-36$ & Debris flow & Trachytic & 0.8 & L5 \\
\hline \multicolumn{5}{|l|}{$119.736 \mathrm{C}$. } \\
\hline $10 \mathrm{R}-1.2-4$ & Debris flow & Trachytic & 2.8 & L6 \\
\hline \multicolumn{5}{|l|}{$119-737 \mathrm{~A}-$} \\
\hline $4 \mathrm{H}-5,110-112$ & Ash layer & Trachytic & 3.7 & L7 \\
\hline $5 \mathrm{H}-5,45-47$ & Ash layer & Trachytic & 3.7 & L8 \\
\hline $6 \mathrm{H}-4,120-122$ & Ash layer & Trachytic & 3.8 & L9 \\
\hline $9 \mathrm{H}-4,76-78$ & Ash layer & Rhyolitic & 4.3 & L10 \\
\hline \multicolumn{5}{|l|}{ 119-737B- } \\
\hline SR-1. 122-124 & Ash layer & Bimodal & 7.8 & LII \\
\hline SR-1, 127-128 & Ash layer & Trachytic & 7.8 & LI2 \\
\hline ISR-4. 66-69 & Ash layer & Basaltic & 28.3 & L13 \\
\hline $21 \mathrm{R}-1,120-122$ & Ash layer & Silica/zeolite & 31.4 & L.14 \\
\hline $22 \mathrm{R}-6,115-117$ & Ash layer & Silica/zeolite & 32.0 & L15 \\
\hline $23 \mathrm{R}-1,28-30$ & Ash layer & Silica/zeolite & 32.0 & L16 \\
\hline $23 R-2,2-3$ & Ash layer & Silica/zeolite & 32.0 & $\mathrm{~L} 17$ \\
\hline \multicolumn{5}{|l|}{ 119-745B- } \\
\hline $12 \mathrm{H}-2,103-105$ & Ash layer & Trachytic & 2.2 & L.18 \\
\hline $12 \mathrm{H}-5,13-144$ & Ash layer & Trachytic & 4.3 & L19 \\
\hline \multicolumn{5}{|l|}{$120-747 \mathrm{~A}$ - } \\
\hline $3 \mathrm{H}-\mathrm{I}, 40-42$ & Ash layer & Trachytic & 3.7 & TI \\
\hline $3 \mathrm{H}-2,119-121$ & Ash layer & Trachytic & 3.7 & $\mathrm{~T} 2$ \\
\hline $3 \mathrm{H}-4,72-74$ & Ash layer & Trachytic & 3.8 & T3 \\
\hline $3 \mathrm{H}-6.62-64$ & Ash layer & Trachytic & 3.8 & $\mathrm{~T} 4$ \\
\hline $17 \times-4,72-74$ & Ash layer & Basaltic & 30.0 & T5 \\
\hline $17 X-6,27-29$ & Ash layer & Basaltic & 30.0 & T6 \\
\hline \multicolumn{5}{|l|}{$120-747 \mathrm{C}$ - } \\
\hline $3 R-3,64-66$ & Mass flow & T-MORB & Danian & $\mathrm{T} 7$ \\
\hline $3 R-3,69-71$ & Mass flow & T-MORB & Danian & $\mathrm{T} 8$ \\
\hline $3 R-3,98-100$ & Mass flow & T-MORB & Danian & T9 \\
\hline $3 R-3,116-118$ & Mass flow & T-MORB & Danian & T10 \\
\hline $3 R-3,144-146$ & Mass flow & T-MORB & Danian & T11 \\
\hline \multicolumn{5}{|l|}{$120-748 \mathrm{C}$. } \\
\hline $79 R-4,93-95$ & Pebble conglomerate & OIB & Turonian? & T19 \\
\hline $79 \mathrm{R}-4,107-109$ & Pebble conglomerate & OIB & Turonian? & $\mathrm{T} 20$ \\
\hline \multicolumn{5}{|l|}{$120-750 \mathrm{~B}-$} \\
\hline $12 W-1,80-82$ & Claystone & T-MORB & Cenomanian? & T12 \\
\hline $12 W-3,96-99$ & Claystone & T-MORB & Cenomanian? & $\mathrm{T} 13$ \\
\hline $13 W-1,50-51$ & Claystone & T-MORB & Cenomanian? & $\mathrm{T} 14$ \\
\hline $14 R-2,25-26$ & Claystone & T-MORB & Cenomanian? & T15 \\
\hline $14 R-1,102-103$ & Claystone & T-MORB & Cenomanian? & T16 \\
\hline
\end{tabular}

Notes: Estimated error in age column $=10 \%$. OIB $=$ oceanic-island basalt and T-MORB $=$ transitional mid-ocean-ridge basalt.

2) is (pre-)Cenomanian(?) in age and overlies tholeiitic T-MORB (Schlich, Wise, et al., 1989).

Ice-rafted, coarser, volcanic debris is dispersed throughout the Neogene to Holocene sediments and treated elsewhere (Breza, this volume). Two intervals from Site 747 revealed a surprising abundance $(20-50 \mu \mathrm{g}$ out of $6 \mathrm{~g}$ total sediment weight) of well-sorted and very fresh, purely volcanogenic fallout ash (see Heider and Inokuchi, this volume).

\section{Macroscopic and Microscopic Description}

\section{Marine Fallout Ash Layers}

Marine fallout tephra layers from the Kerguelen Plateau are 0.5 to $70($ ?) $\mathrm{cm}$ thick, have a sharp base, are gray to green in color, are well sorted, with median grain sizes between 40 and $120 \mu \mathrm{m}$, and do not show cross lamination or erosional contacts toward the base. Reworked ash layers, such as $\mathrm{L} 11$, are only moderately sorted $(3-\mathrm{mm}$ lithic clasts down to
$120 \mu \mathrm{m}$ crystals) and contain some additional green glauconite grains.

Discrete (layers with $>50 \%-70 \%$ volcanic ash; sharp bases) and disseminated (layers with more biogenic material than volcanogenic material; diffuse contacts) ash layers occur as $0.5-12 \mathrm{~cm}$ thick, light gray, green gray, and dark gray intercalations within siliceous to carbonate marine sequences.

Well-sorted to moderately well-sorted, olive gray to dark gray vitric ash and lapilli layers were found in Hole $736 \mathrm{~A}$ in Sections $120-736 \mathrm{~A}-3 \mathrm{H}-1,-3 \mathrm{H}-2,-6 \mathrm{H}-2$, and $-8 \mathrm{H}-2$ and in Section 120-736B-3H (Barron, Larsen, et al., 1989). A typical diatom-ooze-free, silicic ash layer in interval 119$736 \mathrm{~A}-3 \mathrm{H}-1,128-134 \mathrm{~cm}$, has a sharp base and top. It contains normally graded glass and mineral particles. Pumiceous ash and lapilli layers from Site 736, however, are inversely graded. There is continuing debate about whether this "chestnut effect" (the larger grains on the top) is a primary feature caused by mass-flow sedimentation mechanisms, or is an artifact of drilling. The vitric ash to lapilli layers (lapilli tuff in Site 736 core description) in Samples $119-736 \mathrm{~A}-3 \mathrm{H}-1,130-132 \mathrm{~cm}$, and $-7 \mathrm{H}-1,10-12 \mathrm{~cm}$, consist of $90 \%-95 \%$ of blocky to well-rounded, silicic, highly vesicular pumice $(2-5 \mathrm{~mm}$ in diameter, with maximum grain sizes up to $9 \mathrm{~mm})$, some of which contain sanidine $(<300 \mu \mathrm{m}$ long), and a few brown biotite phenocrysts. The silicic pumice particles are fresh and are accompanied by fresh sanidine, Ab-rich plagioclase, hedenbergitic clinopyroxene $(180 \mu \mathrm{m}$ long $)$, and a few quartz grains. Basaltic lithic clasts $(500-600 \mu \mathrm{m})$ contain fresh augite, plagioclase laths, and ore specks set in a light brown, partially recrystallized interstitial glass matrix.

Vitric ash layers (Table 1) containing $<5 \%$ crystal components, range in grain size from 40 to $80 \mu \mathrm{m}$ for light brown, platy to blocky, vesicle-poor sideromelane shards. Maximum grain sizes from 340 to $380 \mu \mathrm{m}$ belong to blocky silicic pumice with tubular vesicles (L18 and L19). Highly vesicular pumice from ash layer T4 reach up to $600 \mu \mathrm{m}$ in size. Blocky pumice from ash layer L12 reaches $920 \mu \mathrm{m}$ in maximum grain size, and associated clear silicic bubble wall shards measure from 40 to $80 \mu \mathrm{m}$. Disseminated ash layer T1 has small $(80-120$ $\mu \mathrm{m})$, vesicle-free glass shards, and larger vesicular glass and pumice shards with grain sizes from 270 to $420 \mu \mathrm{m}$. Crystalpoor vitric ash layers contain sanidine, plagioclase, quartz, hedenbergitic clinopyroxene, and minor biotite, brown amphibole and euhedral zircon, indicating trachytic to alkalirhyolitic sources. Plagioclase, augite, and a few magnetite remnants derive from basaltic sources. Sanidine $(600 \mu \mathrm{m}$ long), clinopyroxene, and opaque phases are rare phenocrysts in the glass shards.

Crystal-rich ash layers (e.g., L2) contain up to $30 \%$ crystals and very few basaltic lithic clasts. Blocky, vesicle-poor, brown glass shards with few plagioclase laths are around 130 $\mu \mathrm{m}$ (up to $900 \mu \mathrm{m}$ ) in diameter. Basaltic lithic clasts range from 120 to $240 \mu \mathrm{m}$ in diameter, some reaching $900 \mu \mathrm{m}$, and are composed of euhedral plagioclase, clinopyroxene, and opaque ore set in a slightly altered, glassy matrix, which accounts for only $5 \%-10 \%$ of the clast. Layer T6 has blocky to round basaltic lithic clasts that have clear feldspar laths set into a fresh, brown, glassy matrix with tiny clinopyroxene and opaque ore microliths.

Tephra layers rich in crystals and lithic clasts (L3) contain $<50 \%$ glassy components, consisting of (1) light brown, plagioclase- and clinopyroxene-bearing pumice with round (100-500 $\mu \mathrm{m}$ ) vesicles; (2) crystal-poor, clear rhyolitic pumice with rare sanidine phenocrysts; and (3) blocky, highly vesicular, fresh brown, plagioclase-bearing basaltic pumice. Lithic 
clasts comprise (1) dense plagioclase and opaque-ore phyric, brown basalts; (2) reddish to opaque, plagioclase-phyric, tachylitic lithic clasts; (3) brown to opaque, vesicular basalts; (4) plagioclase-, clinopyroxene-, and opaque-ore-bearing basalts with a brownish, palagonitized matrix; and (5) sanidine-, biotite-, and blue-green pleochroic amphibole- (arfedsonite) bearing alkali syenite. Opaque-ore-rimmed biotite (opacite), hedenbergite, and Ti-augite, brown amphibole, and sanidine, some containing brown biotite inclusions $(<20 \mu \mathrm{m})$, make up the mineral assemblage.

Shards from ash layers L15 and L16 are completely zeolitized (phillipsite/clinoptilolite?). The morphology and grain size of the zeolitized shards indicate derivation from silicic fallout ash layers. Ash layers L15 and L16 have completely zeolitized pumice (shards up to $1200 \mu \mathrm{m}$ ) and bubble wall shards. Green hedenbergitic-ferroaugitic phenocrysts occur within completely zeolitized platy and pumiceous former glass shards. The crystal assemblage ferroaugite-hedenbergite, sanidine, quartz, and plagioclase(?) reflects the silicic part of these composite ash layers, whereas the basaltic part is made of platy and pumiceous sideromelane shards, some with perlitic cracks, and tachylite and basaltic lithic clasts with abundant plagioclase. Layer L15 has fewer crystals and mafic shards than the ash layer L16 which is similar in composition.

\section{Volcaniclastic Detritus at Site 736}

Pliocene to Quaternary diatom ooze at Site $736(150 \mathrm{~km}$ off Kerguelen Island) contains abundant volcanogenic detritus throughout Unit I (Core 119-736A-1H through Sample 119-736A-6H-1, $75 \mathrm{~cm}$; 0-257.1 mbsf; Barron, Larsen, et al., 1989). Volcanogenic input accounts for as much as $25 \%$, some zeolite, and diatom ooze make up the rest of the sediment. This heterolithic and heterocrystalline, poorly sorted epiclastic sediment with grain sizes up to $2 \mathrm{~mm}$ has a bimodal composition with (1) basaltic components consisting of altered to fresh, well-rounded to subangular, plagioclase-, clinopyroxene-, and magnetite-phyric basalt clasts, poorly vesicular sideromelane, and tachylitic shards, and (2) trachytic to rhyolitic components consisting of clear bubble wall and bubble junction shards, vesicular pumice ash and lapilli, sanidine, biotite, hedenbergitic clinopyroxene, and rare syenitic lithic clasts.

\section{Volcaniclastic Mass Flow at Site 747}

The volcaniclastic mass flow from Site 747 (Unit III) is at least $45 \mathrm{~m}$ thick (the basal contact was not recovered) and contacts the overlying sediment sharply. This unit is a poorly stratified massive sequence with polygenetic, well-rounded to angular, lithic clasts (up to $2.5 \mathrm{~cm}$ in diameter) in a clay matrix. Bedding gets better toward the top, a few centimeterthick, silty to sandy layers are well sorted. The volcaniclastic sequence roughly coarsens downward with the presence of polygenetic lithic clasts such as chert; chalk; fossil debris; aphyric fresh, angular, black basalt; biotite and plagioclase phyric basalt; olivine and clinopyroxene phyric basalt; red, vesicular, well-rounded basalt; and syenite/diorite. The matrix consists of clay minerals, some carbonate, and zeolite. Clay clasts, probably former volcaniclastic rocks, are well sorted and form thin layers.

Samples 120-747C-3R-3, 144-146 cm, -3R-3, 116-118 cm, and $-3 \mathrm{R}-3,98-100 \mathrm{~cm}$, from this unit consist of basaltic lithic clasts (about $15 \%$ ); blocky palagonite to tachylite (5\%-10\%); zeolite clusters; biogene carbonate, phosphate, and chert debris; and brown soft-sediment clasts set in a carbonate matrix. Fresh basaltic lithic clasts contain plagioclase (20-80 $\mu \mathrm{m})$, clinopyroxene $(30-60 \mu \mathrm{m})$, and ore specks. In basaltic lithic clasts that have been more altered, the plagioclase is replaced by zeolite. Olivine pseudomorphs with tiny inclusions of opaque to deep brown $\mathrm{Cr}$ spinel are red and show parallel opaque stringers and smectite matrix. Blocky to round clay particles with platy glass shard morphologies are homogeneously brown. Blocky, vesicular, brown (palagonite) to dark (tachylite) shards measure up to $800 \mu \mathrm{m}$ in diameter and contain $110-\mu \mathrm{m}$-long plagioclase phenocrysts set in a nearly opaque, formerly glassy matrix. Palagonitized, brown, bubble-wall shards are strongly zoned, with darker rims and lighter cores.

Sample $120-747 \mathrm{C}-3 \mathrm{R}-3,69-71 \mathrm{~cm}$, has fresh plagioclase splinters up to $310 \mu \mathrm{m}$, long, and about $10 \%$ of blocky, light brown, homogeneous, clay grains, probably representing former sideromelane shards. Sample 120-747C-3R-3, 98-100 cm, has abundant reddish, basaltic lithic clasts with zeolite-filled bubbles. Zeolite bundles measure up to $600 \mu \mathrm{m}$ in diameter and are especially abundant in Sample 120-747C-3R-3, 144$146 \mathrm{~cm}$. Single crystals are stubby idiomorphic prisms $(240 \mu \mathrm{m}$ long) that grew (1) within vesicles in basaltic lithic clasts, (2) replace plagioclase, and (3) form aggregates in the carbonate matrix.

\section{Volcanogenic Epiclastic Rocks from Site 750}

The uppermost $150 \mathrm{~cm}$ of the epiclastic sediments at Site 750 consist of plastic, reddish brown, ferruginous, kaolinitic silty claystone (Schlich, Wise, et al., 1989). Bedding structures are absent, burrows and laminae are rare. Black, reworked coal particles, authigenic siderite and pyrite, and altered volcanogenic grains become more abundant downward. Siderite laminae and concretions, and a basal siderite cementation indicate reducing conditions in the lowermost 50 $\mathrm{cm}$.

A varicolored, poorly sorted, grain-supported, soft pebble conglomerate to sand (with pebbles $0.5-3 \mathrm{~mm}$ in diameter) with grading and an abrupt change to cross-stratified sand occurs in interval $120-750 \mathrm{~B}-13 \mathrm{~W}-1,30-75 \mathrm{~cm}$.

Kaolinite, pyrite, siderite, goethite, hematite, and a silica component were identified using X-ray diffraction (XRD) techniques (Schlich, Wise, et al., 1989). The brown, plastic clay is composed of kaolinite $35 \%$ and $95 \%$ of the total sediment), and goethite.

Sample $120-750$ B-14R-1, 101-103 cm, is made up of green, blocky to well-rounded particles with grain sizes between 500 and $2000 \mu \mathrm{m}$. Three optically distinct particles can be distinguished:

1. pale brown to green, homogeneous grains without crystal inclusions or vesicles considered to be completely altered, platy, sideromelane shards;

2. light green homogeneous matrix with darker green, concentric bundles of better crystallized smectite showing a higher degree of smectite crystallization; and

3. green to olive-green smectite crystals with high birefringence that fill the interstices between lath-shaped plagioclase pseudomorphs.

The pseudomorphs after plagioclase are now light olivegreen aggregates of fine smectite/chlorite minerals. Some opaque to dirty brown and reddish specks represent Fe-Ti ore aggregates replacing primary ferromagnesian phases. Lithic clasts with plagioclase, clinopyroxene, and opaque ore set in a basaltic, glassy matrix are the inferred original rocks.

The green blocky to round grains probably represent completely altered, glassy, basaltic shards, and minor basaltic lithic clasts. 
Table 2. Major and trace element concentrations of samples from Sites 738,748 , and 750 .

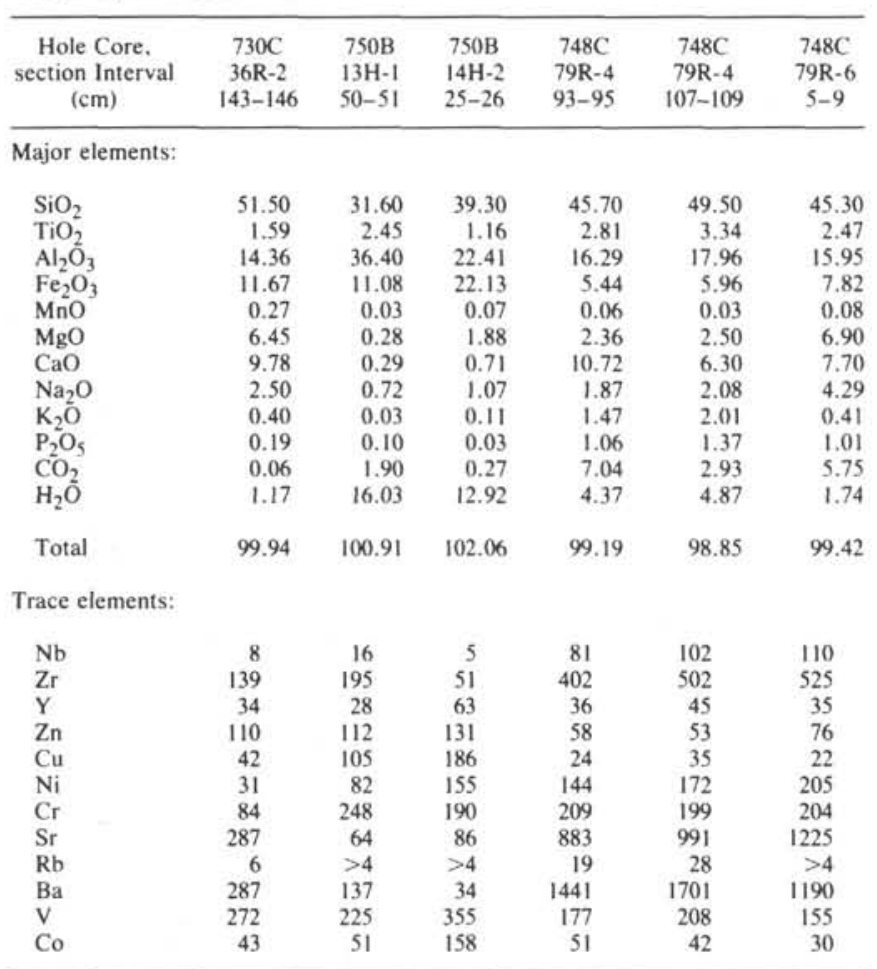

Notes: Sample 119-738C-36R-1, 143-146 cm, illustrates little-altered T-MORB; Samples 120-750B-13W-1, 50-51 cm, and $-14 \mathrm{R}-2,25-26 \mathrm{~cm}$, represent epiclastic claystone of T-MORB origin; Samples 120-748C-79R-4, 93-95 cm and $107-109 \mathrm{~cm}$, are epiclastic pebble conglomerates; and Sample $120-748 \mathrm{C}$ $79 \mathrm{R}-6,5-9 \mathrm{~cm}$, is the underlying, slightly altered alkali-basalt (OIB).

\section{Basal Conglomerate at Site 748}

The basal conglomerate at Site 748 (Subunit IIIC; Schlich, Wise, et al., 1989) contains rounded alkali-basaltic gravel, cobbles, and boulders (up to $40 \mathrm{~cm}$ in diameter), which are-together with molluscan debris-set into a glauconitic and clay matrix. The matrix contains fine-grained volcanogenic debris (plagioclase and $\mathrm{Cr}$-spinel splinters and altered, brown glass relics in a calcite matrix), and is cemented by calcite, siderite, and zeolite. The alkali-basaltic lithic clasts consist of plagioclase remnants and green to brown sheet silicates, zeolite, spongy $\mathrm{Fe}-\mathrm{Ti}$ ore, and carbonate replacing primary constituents. Siderite and zeolite veins, up to $8 \mathrm{~mm}$ thick, cut the biggest boulder. The upper $20 \mathrm{~cm}$ of the underlying alkali basalt are strongly weathered and display round structures similar in dimensions to the overlying conglomerate. This spheroidal weathering provides a simple mechanism for the origin of the alkali-basaltic lithic clasts.

\section{Chemical Compositions}

A few bulk-rock samples from the basal conglomerate at Site 748 and the epiclastic clayey rocks from Site 750 were chemically analyzed (Table 2). Juvenile pyroclastic fragments (phenocrysts, glasses) from marine fallout tephra layers were investigated to determine the composition, provenance, and magmatic evolution of the volcanic sources.

\section{Mass Flow Deposits}

At Site 736, $16 \mathrm{~m}$ of nonlithified Quaternary volcaniclastic debris flows were encountered; at Site 747, a 45-m-thick varicolored volcaniclastic mass flow was drilled; at Site 748 we drilled a 1.2-m-thick basal pebble conglomerate, and at Site 750 , a 52 -m-thick epiclastic terrestrial volcaniclastic sediment (subaerially altered basement). Two chemical analysis each from the latter two epiclastic units were conducted (Table 2). Chemical analysis of a rather fresh T-MORB sample from Site 738 and an alkali basaltic sample from Site 748 are included for comparison.

\section{Volcanogenic Epiclastic Rocks from Site 750}

Epiclastic terrigenous volcaniclastic sediments from Samples 120-750B-14R-2, 25-26 cm, and - $13 \mathrm{~W}-1,50-51 \mathrm{~cm}$, have high $\mathrm{H}_{2} \mathrm{O}(12.9 \%$ and $16.0 \%), \mathrm{Fe}_{2} \mathrm{O}_{3}(11.1 \%$ and $22.1 \%)$, and in particular $\mathrm{Al}_{2} \mathrm{O}_{3}(22.4 \%$ and $36.4 \%)$ concentrations, and low $\mathrm{SiO}_{2}$ (31.6\% and $39.3 \%), \mathrm{MgO}(0.3 \%$ and $1.9 \%), \mathrm{K}_{2} \mathrm{O}(0.1 \%)$, and, in particular, $\mathrm{CaO}(0.3 \%$ and $0.7 \%)$ concentrations when compared with fresh Southern Kerguelen Plateau T-MORB (Site 738).

\section{Basal Conglomerate at Site 748}

Chemical analysis of two samples from the basal conglomerate of Site $748 \mathrm{Cr}$-rich glauconitic sediments (Table 2) have high $\mathrm{Zr}$ (402 and $502 \mathrm{ppm}), \mathrm{Nb}$ (81 and $102 \mathrm{ppm}), \mathrm{Ba}$ (1441 and $1701 \mathrm{ppm}), \mathrm{Ni}$ (144 and $172 \mathrm{ppm}$ ), and Sr (883 and $991 \mathrm{ppm}$ ). The trace element concentrations and especially the $\mathrm{Zr} / \mathrm{Nb}$ ratio of 5 strongly resemble element concentrations and ratios of the underlying alkali basaltic flow.

\section{Marine Fallout Ash Layers}

The ash layers contain fresh juvenile glass shards and mineral fragments that have been analyzed for their major element compositions by grain discrete methods.

\section{Feldspar Compositions}

Compositions of feldspar phenocrysts from ash layers follow distinct trends (Table 3, on microfiche in backpocket; Fig. 3) and can be grouped into several fields. Plagioclases with $\mathrm{An}_{40}$ to $\mathrm{An}_{95}$ compositions (Field A in Fig. 3) belong to basaltic sources. These plagioclases encompass the range of phenocrysts and microphenocrysts from T-MORB of the Kerguelen Plateau (Mehl et al., 1991). The plagioclases $\left(\mathrm{An}_{56}\right.$ to $\mathrm{An}_{80}$ ) from the epiclastic mass flow at Site 747 (Table 3, on microfiche) mostly belong to the basaltic Field A. A subgroup of feldspars, however, has anorthoclase compositions and belongs to Field $\mathrm{C}$. The feldspars from ash layers 119-737A-23R-1, 28-30 cm, and 119-745B-20H-5, $13-14 \mathrm{~cm}$, have distinct, bimodal plagioclase compositions with $\mathrm{An}_{20}$ to $\mathrm{An}_{35}\left(\mathrm{Or}_{1}\right.$ to $\mathrm{Or}_{20}$; Field $\mathrm{B}$ ) and $\mathrm{An}_{1}$ to $\mathrm{An}_{5}$ (Field C). Field B comprises plagioclase with oligoclase compositions belonging to trachytic to andesite basaltic lithic clasts in trachytic tephra layers. Field C comprises anorthoclase from trachytic to alkali rhyolitic tephra layers. More An-rich $\left(\mathrm{An}_{1}-\mathrm{An}_{7}\right)$ anorthoclase within Field $C$ belong to Site 747 ash layers T1-T4, which also contain bytownite to labradorite (Field A) compositions from basaltic sources. The entire range from $\mathrm{Or}_{83} \mathrm{Ab}_{17}$ to $\mathrm{Or}_{2} \mathrm{Ab}_{98}$ in alkali feldspar composition can be found in the trachytic to alkali rhyolitic, crystal-bearing vitric ash and lapilli layers from Site 736 (nearest location toward Kerguelen Island). It is not clear whether nearly pure albite in the ash layers are phenocrysts or are of hydrothermal to epigenetic origin.

In summary, basaltic sources contribute plagioclases with $\mathrm{An}_{48}$ to $\mathrm{An}_{91}$ (Fig. 3, Field A), and trachytic to alkali rhyolitic sources contribute anorthoclases with $\mathrm{Or}_{38}$ to $\mathrm{Or}_{51}$ (Fig. 3, Field C). Intermediate compositions (Fig. 3, Field B) reflect evolved basaltic sources. Bimodal suites have feldspars from within Fields A and C corresponding to minor basaltic lithic clasts and sideromelane shards in trachytic to alkali rhyolitic tephra layers. 


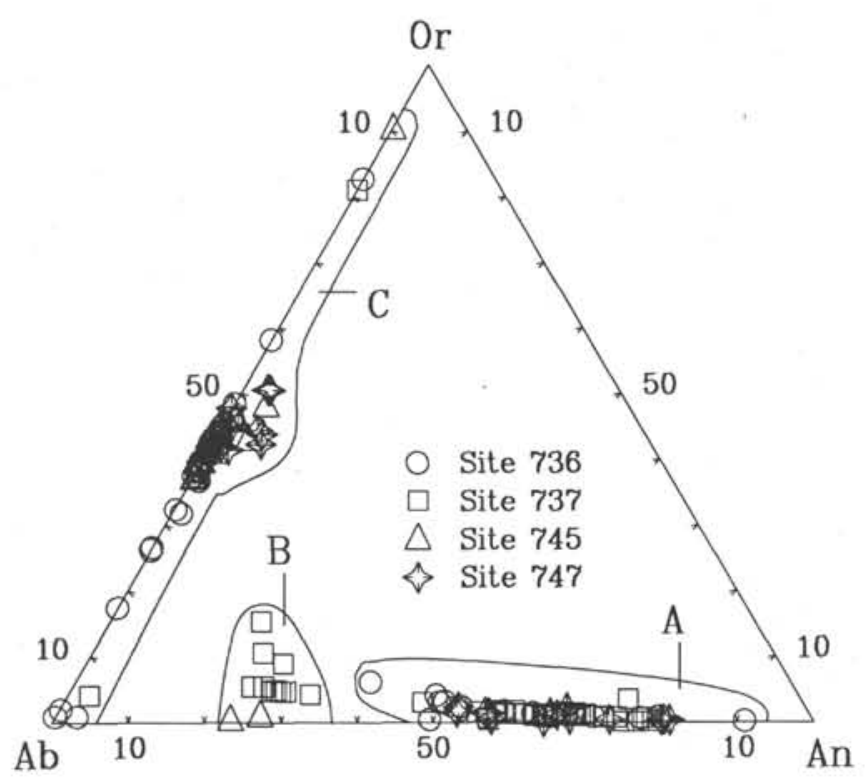

Figure 3. Feldspar compositions in an anorthite (An), orthoclase (Or), and albite (Ab) triangle. An, Or, and $\mathrm{Ab}$ in mol\%.

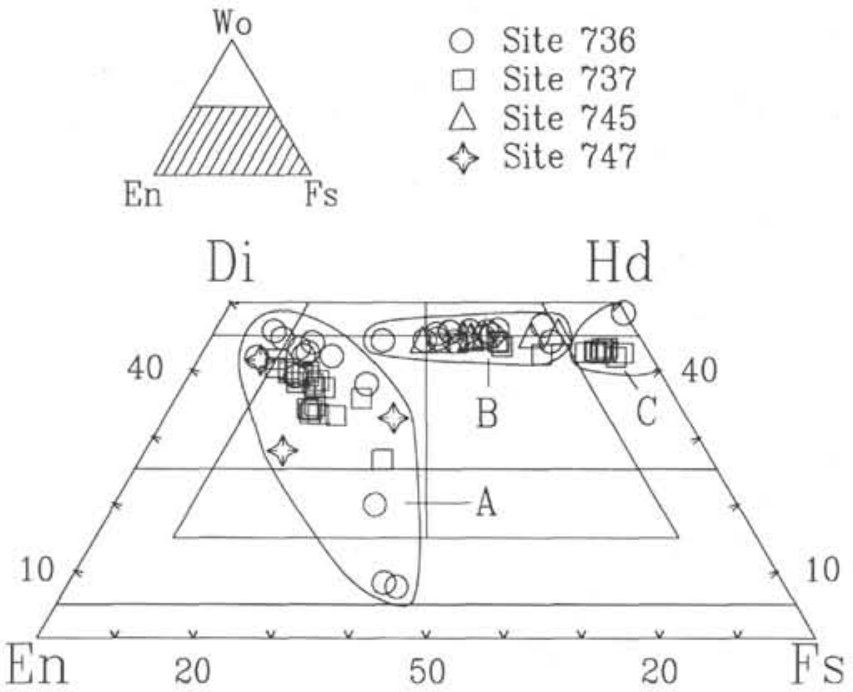

Figure 4. Clinopyroxene compositions in the Wo-En-Fs triangle (division of fields after Deer et al., 1977). Fs, Wo, and En in mol\%.

\section{Clinopyroxene Compositions}

Some clinopyroxenes represent microphenocrysts from basaltic lithic clasts and very minor phenocrysts from silicic pumice. Most are splinters of clinopyroxene phenocrysts from crystal-rich tephra layers. Enstatite (En), wollastonite (Wo), and ferrosalite (Fs) always make up more than $85 \mathrm{~mol} \%$ (Table 4 , on microfiche in backpocket). Al-, Ti-, and Na-rich pyroxenes indicative for OIB sources are lacking, as well as aegirine, typical for peralkaline phonolitic to rhyolitic, latestage crystallization.

The clinopyroxenes (nomenclature after Morimoto, 1988) are pigeonite (two samples), augite (the bulk of basalt-derived pyroxenes), diopside (two samples), and hedenbergite. In a more detailed division (Fig. 4; division and nomenclature after Deer et al., 1977), the pyroxenes plot into the fields of intermediate pigeonite, subcalcic augite, augite, salite, fer- roaugite to ferrosilite, hedenbergite and ferrohedenbergite. Augites with $\mathrm{TiO}_{2}$ between $1 \%$ and $2 \%$, and $\mathrm{Al}_{2} \mathrm{O}_{3}>2 \%$ (Table 4 , on microfiche) are Ti-bearing augites (Yagi and Onuma, 1967) and indicate a more alkalic character of the host basaltic magma. They correspond to Ti-bearing augites from slightly alkaline Kerguelen Plateau T-MORB (Mehl et al., 1991). Diopsidic augites to salites have higher $\mathrm{Cr}_{2} \mathrm{O}_{3}$ concentrations $(0.35 \%-0.98 \%)$ and $\mathrm{En}_{13}$ to $\mathrm{En}_{7}$ (Table 4, on microfiche). These $\mathrm{Cr}$-rich clinopyroxene match compositions of similar pheno/xenocrysts from the T-MORB of the Kerguelen Plateau (Mehl et al., 1991) and are interpreted as xenocrysts or early phenocrysts.

Pigeonite and subcalcic augite belong to microphenocrysts from basaltic lithic clasts in silicic tephra layers L2 and L3 at Site 736, and En-rich augite to high-Ti basaltic ash layers (e.g., T5 and T6 at Site 747). The bulk of the pyroxenes is augitic (Fig. 4, Field A) indicating tholeiite basaltic sources. Ferrosalites and Wo-rich ferroaugites are second in abundance (Fig. 4 , Field $\mathrm{B})$ and display a narrow range in $\mathrm{Wo}\left(\mathrm{Wo}_{40}\right.$ to $\left.\mathrm{Wo}_{43}\right)$ with a continuous increase in the Fs-molecule on account of decreasing En. Hedenbergite and ferrohedenbergites form a third group (Fig. 4, Field C) and stem from a crystal-rich layer with completely zeolitized former glass shards and pumice. The hedenbergitic pyroxenes are $\mathrm{Al}, \mathrm{Na}$, and $\mathrm{Ti}$ poor and form a distinct group.

The clinopyroxene analyzed can be attributed to two main sources:

1. slightly alkali-enriched T-MORB basaltic sources that developed intermediate pigeonite and subcalcic augite, and augite to diopsidic/salitic augite as major and late crystallization phases (the $\mathrm{Cr}$-rich diopsidic augites are considered to be early phenocrystic or previous xenocrystic crystallization phases related to more primitive magma compositions); and

2. trachytic to alkali rhyolitic sources that crystallized ferrosalitic to hedenbergitic clinopyroxene (a linear trend with constant Wo indicates differentiation of the source magma starting with ferrosilite and developing toward hedenbergites).

\section{Zeolites}

Zeolites occur as (1) stubby, well-crystallized prisms within the epiclastic mass flow from Site 747, and (2) aggregates replacing former silicic glass shards. Exact zeolite classification and genesis cannot be given as it requires XRD analysis. Here we only report on broad chemical differences (Table 5, on microfiche in backpocket; Fig. 5) and probable zeolite species.

Four major types of zeolite can be recognized chemically (Table 5, on microfiche; Fig. 5):

1. zeolite (mordenite/heulandite/clinoptilolite?) low in $\mathrm{K}_{2} \mathrm{O}$ $(<1.5 \%)$ and high in $\mathrm{CaO}(3.6 \%-5.2 \%)$;

2. CaO- and $\mathrm{K}_{2} \mathrm{O}$-poor $(<1 \%$ and $0.1 \%$, respectively) and $\mathrm{Na}_{2} \mathrm{O}$-rich $(10.6 \%-11.8 \%)$ analcime;

3. phillipsite high in $\mathrm{K}_{2} \mathrm{O}(3.3 \%-3.8 \%)$, intermediate in $\mathrm{Na}_{2} \mathrm{O}(>5.5 \%)$, and low in $\mathrm{CaO}(1.7 \%-3.1 \%)$; and

4. zeolites high in $\mathrm{K}_{2} \mathrm{O}(3.9 \%-6.2 \%)$ and poor in $\mathrm{CaO}$ $(<0.9 \%)$, which also have high $\mathrm{Al}_{2} \mathrm{O}_{3}(17.4 \%-20 \%)$ concentrations.

In the $\mathrm{Na}$ vs. Si diagram (Fig. 6), a broad negative correlation can be seen. Al also increases with $\mathrm{Na}$, suggesting $\mathrm{Na}+\mathrm{Al}$ substitution for $\mathrm{Si}$. The change in $\mathrm{Na} / \mathrm{Si}$ and $\mathrm{Si} / \mathrm{Al}$ ratios may reflect either source material or diagenesis-related solution characteristics. 


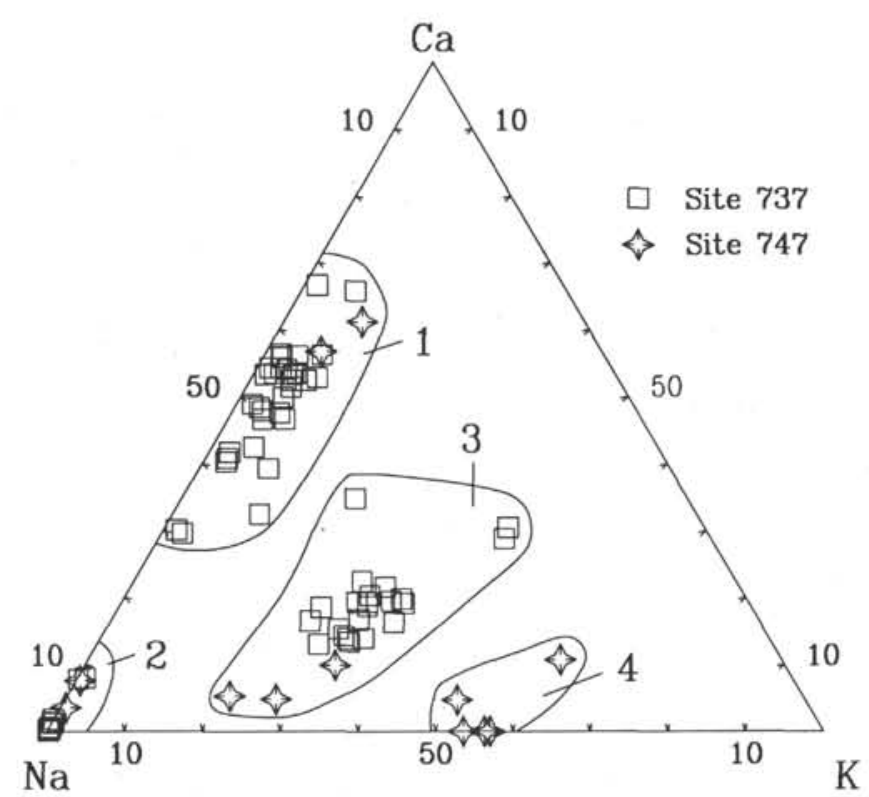

Figure 5. Zeolite compositions in a K-Ca-Na triangle. $\mathrm{K}, \mathrm{Ca}$, and $\mathrm{Na}$ in atomic percent.

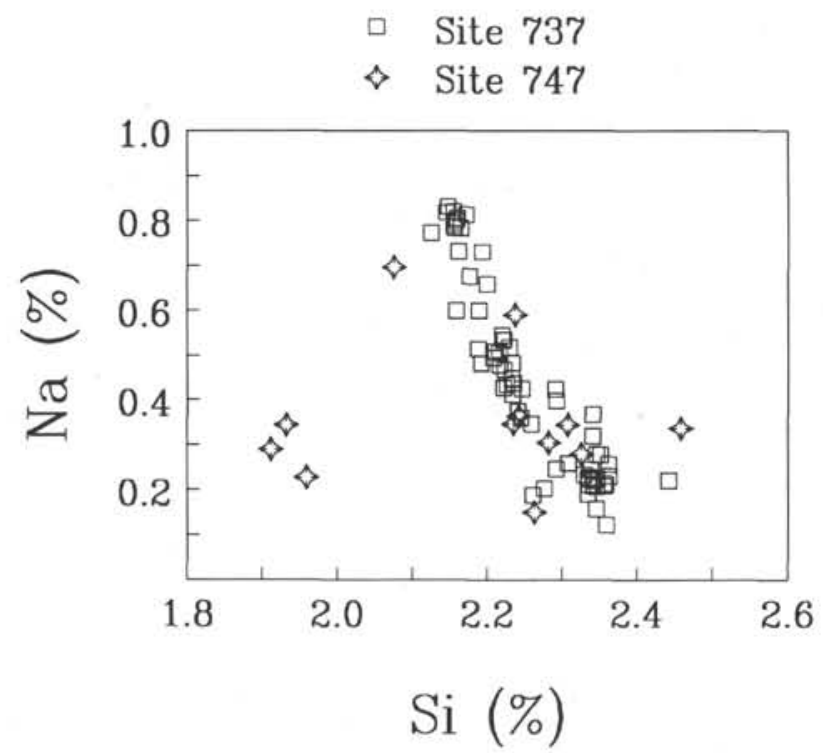

Figure 6. Na vs. Si concentrations (atomic percent) of zeolite.

\section{Glass Compositions}

The volcanic glasses analyzed are isotropic and fresh, major element oxide sums ranging from 93\% to $99 \%$ (Table 6, on microfiche in backpocket). Brown, basaltic glasses have higher totals $(>97 \%)$ than colorless trachytic to rhyolitic glasses $(93 \%-97 \%)$. The difference is attributed to higher relative $\mathrm{Na}$-loss during microprobe analysis for silicic glasses than for basaltic glasses, higher volatile concentrations of silicic glasses due to advanced differentiation, and hydration of glasses. Na-loss due to volatilization is estimated to account for $0.5 \%-1.5 \%$ in silicic glasses, and $<0.2 \%$ in basaltic glasses. Volatile concentrations for silicic glasses are estimated to about $2 \%-4 \%$ for silicic glasses and $<2 \%$ for basaltic glasses. Isotropic glasses are thought to represent primary magma compositions that are only affected by hydration and

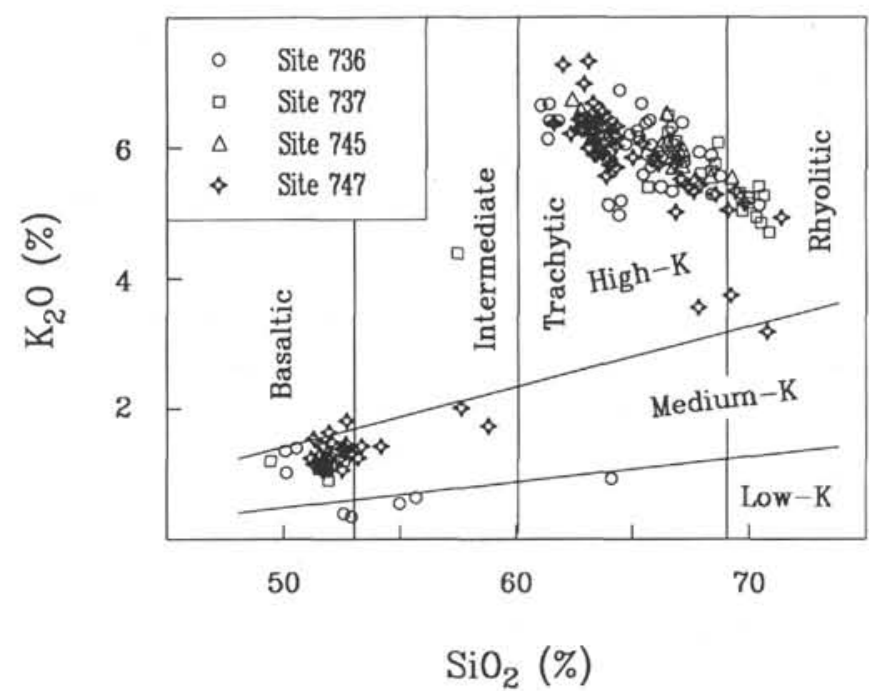

Figure 7. $\mathrm{K}_{2} \mathrm{O}$ vs. $\mathrm{SiO}_{2}$ (in wt\%) classification diagram (after LeMaitre, 1989).

not by significant element exchange with seawater or pore fluids. We will not discuss $\mathrm{Na}$ concentrations, which were affected by volatilization, and $\mathrm{Mn}$ and $\mathrm{Cr}$ concentrations, which were near the detection limit.

\section{Classification}

In Figure 7, the glasses are divided into (1) a low-K series; (2) a medium-K series, which comprises nearly all the basaltic glass shards; and (3) a high-K trachytic and rhyolitic series. In a total-alkali vs. silica (TAS) diagram (e.g., LeMaitre, 1989), the silicic shards would also cover trachytic and rhyolitic fields instead of the dacitic field, despite the $\mathrm{Na}_{2} \mathrm{O}$ deficiencies caused by volatilization.

Plots of major elements vs. $\mathrm{SiO}_{2}$ (Figs. 7 and 8) indicate (1) basaltic glasses with $\mathrm{SiO}_{2}<53 \%$ and $\mathrm{MgO}>3.8 \%$; (2) trachytic to rhyolitic glasses with $\mathrm{SiO}_{2}>60 \%$ and $\mathrm{MgO}<1 \%$; and (3) a very few intermediate trachybasaltic to andesite basaltic glass compositions with $\mathrm{SiO}_{2}=53 \%-60 \%$ and $\mathrm{MgO}=1.5 \%$ $3.5 \%$. The latter are important, however, to explain the gap between the basaltic and silicic glass shards.

Basaltic glasses have $\mathrm{SiO}_{2}$ concentrations $<53 \%$ and $\mathrm{MgO}$ $>3.8 \%$ and are especially variable in $\mathrm{TiO}_{2}, \mathrm{FeO}, \mathrm{P}_{2} \mathrm{O}_{5}$, and $\mathrm{Al}_{2} \mathrm{O}_{3}$ concentrations (Fig. 8; Table 6, on microfiche). Low-K basaltic glasses occur (1) as single microlitic, vesicular, fresh, brown shards in silicic tephra layer L4, where they are attached to much larger silicic pumice; and (2) as plagioclase phyric, brown vesicular shards in silicic tephra layer L3. The low-K shards from layer $\mathrm{L} 4$ have low $\mathrm{TiO}_{2}(1.4 \%)$ and $\mathrm{FeO}$ $(8.9 \%)$ concentrations, and high $\mathrm{Na}_{2} \mathrm{O}(4.1 \%), \mathrm{Al}_{2} \mathrm{O}_{3}(16.2 \%)$, and $\mathrm{MgO}(5.7 \%)$ concentrations. The $\mathrm{L} 3$ sample is more evolved, with low $\mathrm{FeO}$ and $\mathrm{TiO}_{2}$ and high $\mathrm{Na}_{2} \mathrm{O}(4.4 \%)$ concentrations. The low $\mathrm{K}$ and $\mathrm{Ti}$ basalts (LTB) are least enriched in terms of incompatible and high-field-strength (HFS) element (K, Ti, and P; Fig. 8) concentrations and represent a primitive basaltic pulse during an otherwise highly explosive silicic volcanic episode.

The medium-K basaltic series shows considerable scatter in $\mathrm{TiO}_{2}, \mathrm{P}_{2} \mathrm{O}_{5}$, and $\mathrm{K}_{2} \mathrm{O}$. The glasses have high $\mathrm{TiO}_{2}(3.2 \%$ $4 \%$ ), and low $\mathrm{Al}_{2} \mathrm{O}_{3}(12.4 \%-13.9 \%$ ) concentrations (Fig. 8 ) and are considered to be high-Ti basalts (HTB). More evolved trachy-basaltic and rhyolitic glass shards with low $\mathrm{K}_{2} \mathrm{O}(1.7 \%$ and $2 \%$ for trachy-basaltic shards, $3.7 \%$ for rhyolitic shards) 

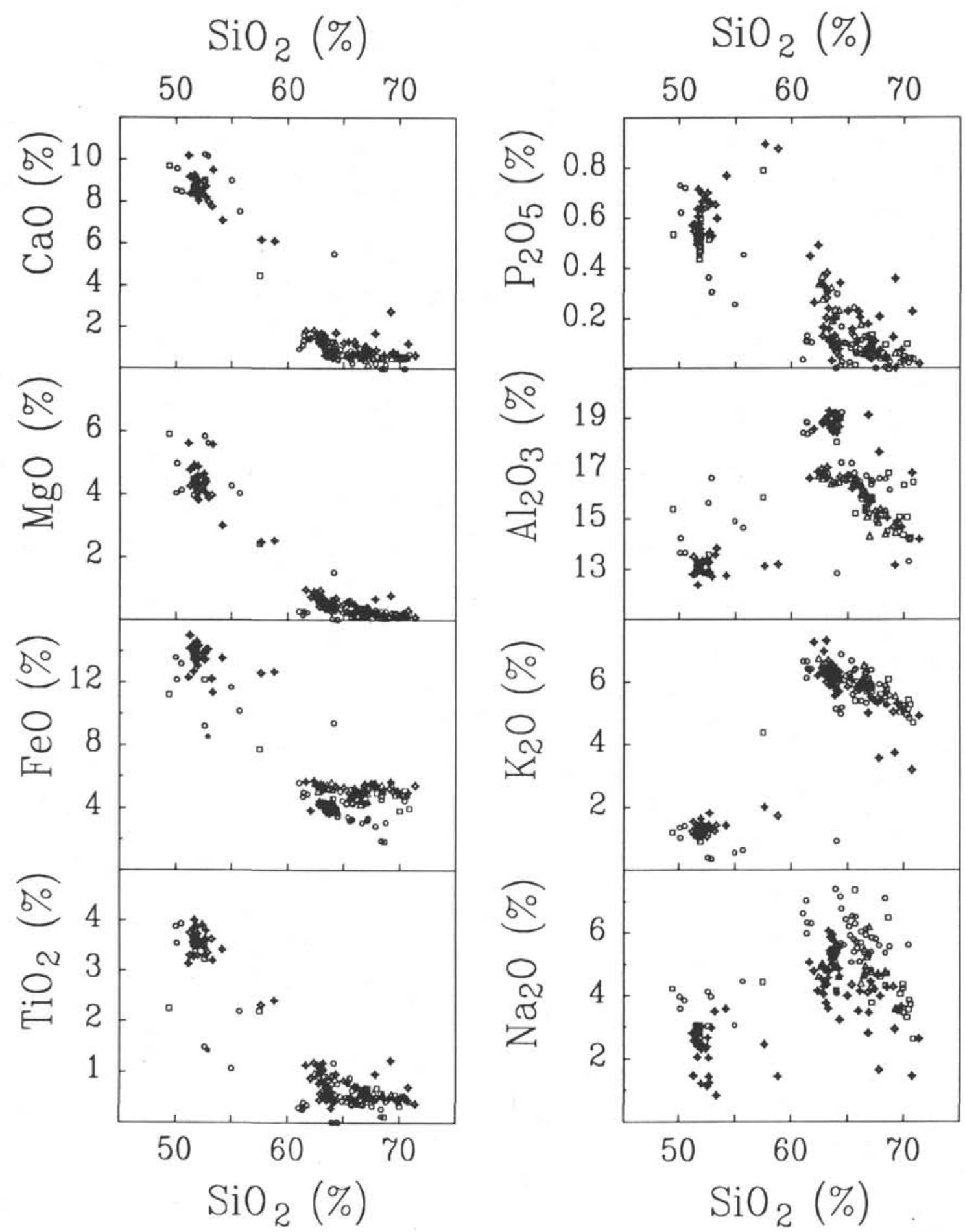

Figure 8. Major elements vs. $\mathrm{SiO}_{2}$ (in wt\%) diagram. Symbols as in Figure 3.

concentrations occur within layers T5 and T6, indicating that a bimodal suite was erupted.

HTB ash layer L13 is an example of a compositionally very homogeneous eruption (Table 6 , on microfiche), as $\mathrm{SiO}_{2}$ ranges from $51.5 \%$ to $52.6 \%$ and $\mathrm{TiO}_{2}$ from $3.23 \%$ to $3.65 \%$. The basaltic glasses analyzed comprise (1) a LTB (low-K) series that has low incompatible and HFS element concentrations; and (2) a HTB (medium-K) series with a very small compositional variation in ash layer L13 and a larger compositional variation in HTB ash layers L5 and L6.

Silicic glasses with $\mathrm{SiO}_{2}$ concentrations $>60 \%$ and $\mathrm{MgO}$ concentrations $<1 \%$ (Fig. 8 ) are high-K trachytic and rhyolitic glasses (Fig. 7) except for single, accidental(?) low-K silicic shards from HTB ash layers. High-K silicic shards have high $\mathrm{K}_{2} \mathrm{O}\left(4.3 \%-7.2 \%\right.$ ) and $\mathrm{Na}_{2} \mathrm{O}$ (up to $7.1 \%$ ) concentrations (Fig. 8 ). The corresponding silicic ash layers contain alkali feldspar 


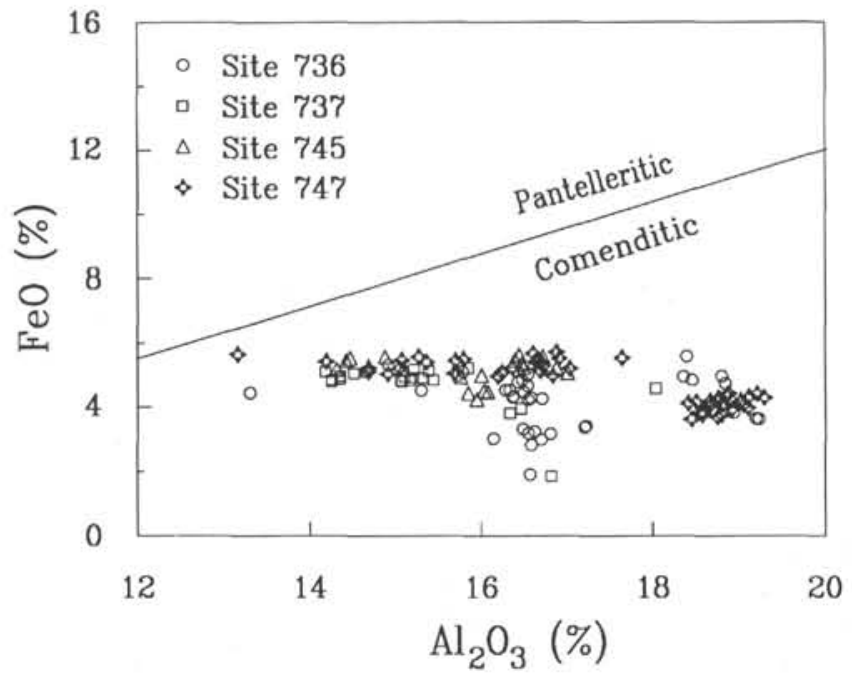

Figure 9. $\mathrm{FeO}$ vs. $\mathrm{Al}_{2} \mathrm{O}_{3}$ (in wt\%) variation diagram to divide pantelleritic from comenditic rocks (after LeMaitre, 1989).

and only occasional quartz as the light mineral phenocrysts. The silicic ashes form a group of predominant trachytic to minor alkali rhyolitic ashes. They plot within the comenditic field (Fig. 9).

A diagram of $\mathrm{Al}_{2} \mathrm{O}_{3}$ vs. $\mathrm{SiO}_{2}$ (Fig. 8) reveals two different groups with $\mathrm{Al}_{2} \mathrm{O}_{3}<17 \%$ and $\mathrm{Al}_{2} \mathrm{O}_{3}>18 \%$. A more detailed look at silicic ash layer $\mathrm{T} 2$ shows that high $\mathrm{Al}_{2} \mathrm{O}_{3}$ and $\mathrm{Na}_{2} \mathrm{O}$ are accompanied by low $\mathrm{FeO}$ and $\mathrm{TiO}_{2}$ concentrations. The second group of silicic ashes has lower $\mathrm{Al}_{2} \mathrm{O}_{3}$ concentrations that correlate positively with $\mathrm{K}_{2} \mathrm{O}$, negatively with $\mathrm{SiO}_{2}$, and has rather high, constant $\mathrm{FeO}(5.1 \% \pm 0.5 \%)$ concentrations toward more differentiated compositions.

\section{DISCUSSION}

\section{Timing, Mode of Emplacement, and Geotectonic Significance}

\section{Epiclastic Rocks}

\section{Site 747 Volcaniclastic Mass Flows}

Site 747 volcaniclastic mass flows transported a Maestrichtian fauna into a deep-water (around $2 \mathrm{~km}$ ) Danian pelagic environment (Aubry and Berggren, 1989). A hiatus of about 4 m.y. separates volcaniclastic Unit III in Site 747 with Danian faunal elements from the overlying upper Paleocene sediments (Aubry and Berggren, 1989). Poor sorting and bedding, angular and well-rounded heterolithic clasts in a clay matrix, and massive (several meters in thickness) units suggest a mass flow origin of Unit III at Site 747, possibly occurring in three successive pulses.

The sequence is an epiclastic volcanogenic debris flow containing subaerially weathered and eroded T-MORB and shallow-marine, carbonate-cemented volcaniclastic components that were shed into the ocean and subsequently mixed with biogenic debris indicative of a high-productivity environment. High biogenic productivity and poorly sorted but highly voluminous epiclastic volcanogenic mass flows may indicate a nearshore (several kilometers in distance) clastic apron proximal to an ocean island or a faulted oceanic basement block. The volcaniclastic mass flow, which is a seismic reflector, denotes a major tectonic event in the Late Cretaceous (Danian) related to faulting, vertical displacement, and ero- sion of oceanic T-MORB basement blocks and overlying carbonate cemented volcaniclastics (Schlich, Wise, et al., 1989; Aubry and Berggren, 1989). The site of subaerial and submarine erosion could be along an offshoot of the $77^{\circ} \mathrm{E}$ Graben system, some $67 \mathrm{~km}$ to the southeast of Site 747 (Schlich, Wise, et al., 1989).

\section{Site 748 Basal Conglomerate}

The Turonian(?) basal conglomerate contains rounded pebbles and boulders of the underlying alkali basaltic flow. The epiclastic volcanogenic conglomerate is interpreted to mark the base of a major marine transgression onto the Southern Kerguelen Plateau (Banzare Bank and Raggatt Basin) andtogether with the overlying $\mathrm{Cr}$-rich glauconitic sequence (Bitschene et al., this volume)-denotes erosion and reworking of ocean-island-type volcanic edifices. The basal transgressive conglomerate heralds submergence of parts of the Southern Kerguelen Plateau (Raggatt Basin) after cessation of basaltic volcanic activity (>90 Ma).

\section{Site 750 Epiclastic Sediment}

The (pre-)Cenomanian(?) epiclastic sequence of claystone and siltstone with some sandy to conglomeratic intervals contains fragments of land plants, kaolinite, authigenic pyrite and siderite, and altered basaltic clasts. This indicates formation and sedimentation in a warm, temperate to subtropical climate with sufficient rainfall to weather the surrounding and underlying basalt. The soft pebble conglomerate indicates fluvial conditions, whereas authigenic siderite and abundant coal fragments suggest marshy flood plain to coal swamp environments (Schlich, Wise, et al., 1989).

Compared with T-MORB of the SKP (Table 2; Mehl et al., 1991), the volcanogenic epiclastic claystones have lost $\mathrm{Ca}, \mathrm{K}$, $\mathrm{Rb}, \mathrm{Sr}, \mathrm{Si}$, and $\mathrm{Mg}$, whereas they gained $\mathrm{Fe}, \mathrm{Al}$, and water. Immobile elements such as $\mathrm{Zr}$ ( $51 \mathrm{ppm}$ and $195 \mathrm{ppm}), \mathrm{Nb}$ (5 ppm and $16 \mathrm{ppm})$, and $\mathrm{TiO}_{2}(1.2 \%$ and $2.5 \%)$, and especially the $\mathrm{Zr} / \mathrm{Nb}$ ratio of $10-17$ indicate the T-MORB origin of the volcaniclastic sediments.

\section{Explosive Volcanism}

Marine fallout tephra layers from the Kerguelen Plateau are Oligocene (four layers from Sites 737 and 747), late Miocene (one layer, but incomplete shipboard sampling), and Pliocene-Pleistocene (bulk of the layers) in age (Fig. 10). Oligocene ashes are basaltic with minor silicic shards. The zeolitized ash layers of Oligocene age with their unaltered phenocrysts, however, indicate silicic volcanic activity. The Miocene tephra have bimodal compositions. Pliocene-Pleistocene ash layers are more silicic and lack basaltic glasses. The youngest tephra layers again have bimodal compositions; however, unlike the Oligocene ash layers, silicic shards are dominant. Figure 10 suggests major explosive pulses in the late Oligocene, which may indicate growth of the source volcano from abyssal plateau depths to sea level or above. These pulses (at least two eruptions) were bimodal in composition, with strong basaltic activity.

After a lull of about $22 \mathrm{Ma}$ (although hiatuses, unfavorable wind conditions, erosion, and sea-ice cover may have prevented ash deposition onto the seafloor during that interval), explosive volcanism returned in the late Miocene, when bimodal ashes with predominant silicic glasses were dispersed, indicating advanced magmatic differentiation stages. Explosive volcanism peaked with silicic and only subordinately intermediate ashes in the Pliocene-Pleistocene. Strongly bimodal volcanic activity with trachytic and minor basaltic compositions occurred in the Quaternary. Basaltic shards with $\mathrm{MgO}>4 \%$ show high-Ti $\left(3.5 \%-4.1 \% \mathrm{TiO}_{2}\right)$, and 


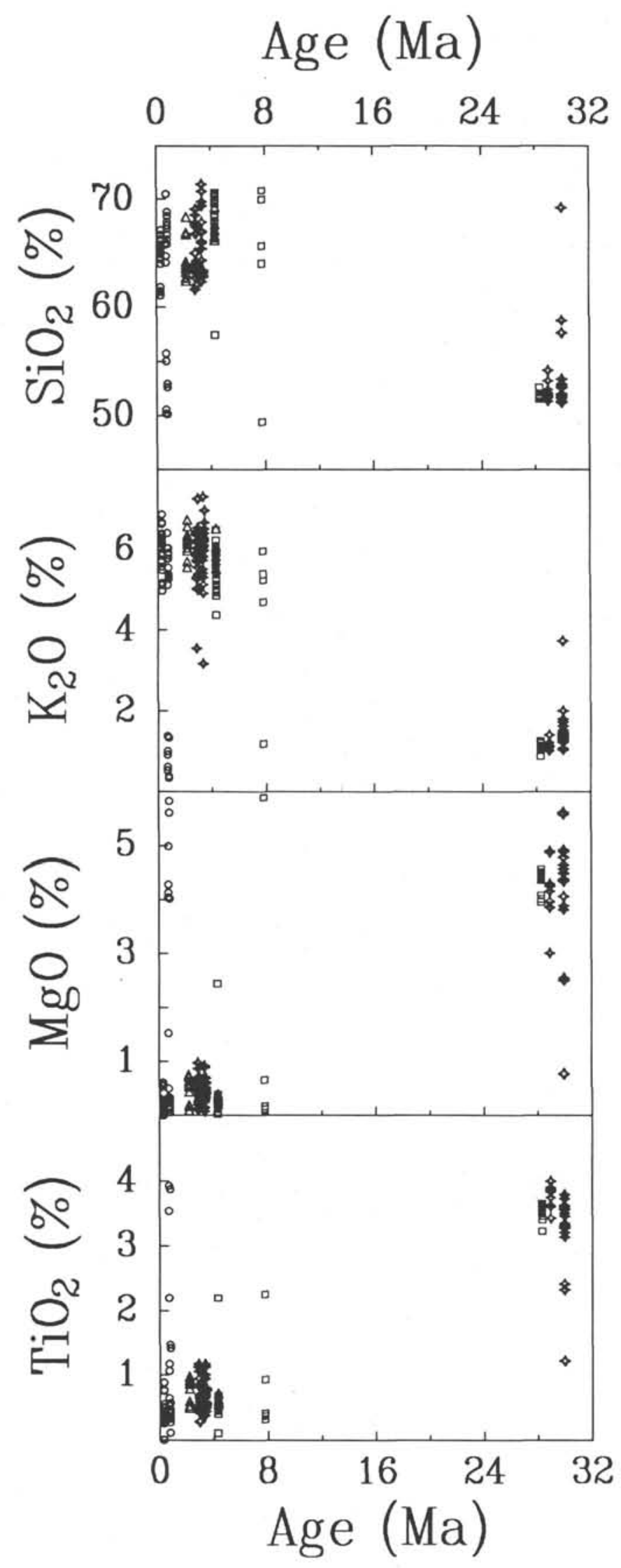

Figure 10. Selected major element concentrations (in wt \%) of glass shards from marine ash fallout layers vs. approximate age (in Ma). Symbols as in Figure 3. low $\mathrm{Ti}(1.5 \%-2.2 \%)$ concentrations, indicating two different sources contributing basaltic magma batches.

In Quaternary silicic tephra layers L3 and L4, a few basaltic glass shards are attached to silicic pumice. This, and the nearly complete lack of intermediate glass compositions, suggests that new, Quaternary basaltic magma was injected into an already existing, silicic magma chamber, which then exploded and discharged. This mechanism would also explain the bimodal composition of some silicic Kerguelen Plateau fallout tephra layers with minor basaltic shards. Alternatively, influx of external water into shallow magma chambers or open contact of magma and seawater can also explosively discharge magma. This phreatomagmatic model may explain otherwise less explosive, homogeneous basaltic eruptions. Though quite speculative, the two physical eruption models may account for eruption of the Quaternary bimodal tephra layers L4 and L3 (basaltic influx and superheating), and the homogeneous basaltic ash layer L13 (phreatomagmatic).

Thicknesses in the centimeter range and wide areal distribution of the ash layers, size, sorting and morphology of glass and crystal particles $(<120 \mu \mathrm{m})$, and the overall high glass contribution clearly point to explosive origin and airborne dispersal of the volcanic ash. Vesicularity of silicic and basaltic shards indicates explosive volcanism on land or in shallow waters, when water pressure was not high enough to prevent degassing and vesiculation of explosively erupting basaltic and silicic magmas. Only zeolitized silicic ash layers L14-L16 carry cracked basaltic-lithic clasts and vesicle-free sideromelane shards, which may indicate shallow to moderately deep submarine eruptions during the early stages of seamount evolution.

The $20-50-\mu \mathrm{m}$ grain size of the fine ash particles, with basaltic and trachytic compositions dispersed in two sediment samples (see Heider and Inokuchi, this volume), indicate fallout after highly explosive eruptions. Plinian eruptions are inferred for dispersal of the crystal-bearing ashes with homogeneous grain sizes (e.g., L13). Vitric ashes with a low crystal concentration may also result from distal co-ignimbrite ashes, which generally have low crystal concentrations. In the case of crystal-rich ash layers, we have either (1) to infer explosion and disruption of a crystal-mush-rich magma chamber, or (2) reworking and elutriation of the less dense glass and pumice particles. Density sorting and elutriation of the less dense glass and pumice particles may occur because of the reworking and redeposition of earlier ash layers.

The marine ash layers from Sites $736,737(150 \mathrm{~km}$ away from Kerguelen Island), 745, 747, and 750 (up to $900 \mathrm{~km}$ away from Kerguelen Island) are distal fallout ashes from powerful Plinian and co-ignimbrite eruptions. Site 736 and 737 ash layers are more proximal fallout layers, and crystal-rich ash layers probably have experienced some reworking.

\section{Source Regions of the Marine Ash Layers}

Today, strong westerly to northwesterly winds rule the Southern Hemisphere south of $40^{\circ} \mathrm{S}$, as indicated by an ash plume from Heard Island volcanic activity in January 1985 that was reported to extend up to $20-25 \mathrm{~km}$ in southeasterly directions (McClelland et al., 1989). The Heard Island-Big Ben stratovolcano is an example of recent volcanic activity on the Northern Kerguelen Plateau and shows what might have happened during previous, more explosive volcanic events on Heard and Kerguelen islands, which led to the deposition of the marine ash layers encountered during Legs 119 and 120. Very similar conditions are inferred for paleowinds and paleocurrents since the Oligocene. Thus, source regions on Antarctica, Broken Ridge, or Ninetyeast Ridge, Australia, or somewhere to the east or south of the sites with fallout tephra 
layers can be ruled out for windborne dispersal of volcanic ash. The origin of the ash layers must lie to the west or north of the sites with fallout tephra layers. The Kerguelen Archipelago (Kerguelen and Heard islands, situated on the Northern Kerguelen Plateau) is the most likely source for marine fallout tephra layers.

Kerguelen and Heard islands have been magmatically active at least since the late Oligocene (Watkins et al., 1974; Dosso et al., 1979), with pronounced igneous activity on Kerguelen Island in a 5-m.y. late Miocene to Pliocene time interval. This time span fits increased ash layer frequencies in the interval from 8 to $3 \mathrm{Ma}$ (Fig. 10). Kerguelen and Heard islands also have basanitic and all kinds of MORB lavas ( $80 \%$ of Kerguelen Island is covered by basaltic lavas; Gautier et al., 1989) as well as evolved magmatism with phonolitic, trachytic, and rhyolitic compositions (Watkins et al., 1974). Watkins et al. (1974) reported on the following volcanic edifices from Kerguelen Island: (1) shield volcanoes with alkaline and transitional basalt flows and minor trachytic and rhyolitic flows (the De Courbet shield is surmounted by a 12-km-wide caldera); (2) trachytic and alkali basaltic stratovolcanoes; (3) adventive cones with basanitic/phonolitic and trachytic/rhyolitic plugs and flows.

The timing and composition of the tephra fallout layers investigated fit the tholeiitic to slightly alkali-basaltic activity on Kerguelen Island. Trachytic to rhyolitic compositions of the tephra layers resemble trachytic and rhyolitic rocks (Watkins et al., 1974) on Kerguelen Island, especially in their $\mathrm{SiO}_{2}$, $\mathrm{K}_{2} \mathrm{O}$, and $\mathrm{TiO}_{2}$ concentrations. Calderas and stratovolcanoes, active since the Oligocene, on Kerguelen Island (tholeiitic, trachytic, rhyolitic), Heard Island (basanitic to phonolitic), and, with less probability, Macdonald Seamount or Crozet Island are inferred to be the sources of the marine fallout layers investigated. Kerguelen and Heard island are $<900 \mathrm{~km}$ away from ash layers at Sites 745,747 , and 750 . More remote are the Crozet Islands ( $>2500 \mathrm{~km}$ away) and even farther are the Prince Edward Islands (>3200 km).

\section{Evolution of Ash Layer Glass Compositions}

In general, several features and processes can account for the genesis and evolution of oceanic, basaltic, and silicic magmas: (1) source rock composition (depleted vs. enriched or metasomatized upper mantle) and degree of partial melting; (2) equilibrium melting or fractional melting; (3) remelting of oceanic crust; (4) differentiation through fractional crystallization; and (5) mixing of different magma batches, or contamination.

The genesis of the basaltic rocks can only poorly be constrained as trace element and isotope data are lacking. With $\mathrm{MgO}<6 \%$, and $\mathrm{SiO}_{2}>49.5 \%$, the basaltic shards are also far from having primitive compositions. It is inferred that the evolved basaltic glass compositions dealt with here are the result of previous fractionation of $\mathrm{Fe}-\mathrm{Mg}$ minerals. This fractionation, however, would not produce the differences in $\mathrm{TiO}_{2}$ and $\mathrm{P}_{2} \mathrm{O}_{5}$ at the same $\mathrm{MgO}$ level. High $\mathrm{Ti}(\mathrm{K}, \mathrm{P})$ and low $\mathrm{Ti}(\mathrm{K}, \mathrm{P})$ concentrations (Table 6 , on microfiche) of basaltic glasses with similar $\mathrm{MgO}$ concentrations are thought to indicate different sources: (1) an enriched upper mantle source for high K, P, and Ti T-MORB; and (2) a depleted or less-enriched upper mantle source for low $\mathrm{K}, \mathrm{P}$, and Ti N/T-MORB.

This is consistent with the findings from southern Indian Ocean basalts (e.g., LeRoex, 1987; Mehl et al., 1991), in which high-Ti basalts (E/T-MORB) also have higher incompatible trace element concentrations than low-Ti basalts (N-MORB). Thus, partial melting of an enriched upper mantle region would be the process and source of the generation of high-Ti basaltic magmas, which are inferred to be the parent magmas for the evolved compositions $\left(\mathrm{MgO}<6 \%, \mathrm{CaO}<10 \%\right.$, and $\mathrm{SiO}_{2}>49.5 \%$ ) of the high-Ti basaltic glasses. To what extent our evolved basaltic glass compositions are related to the remelting of oceanic crust cannot be assessed here.

Linear regression lines in binary element variation diagrams are strong indicators for the mixing of two end-member magmas. Major element plots vs. $\mathrm{MgO}$ as a differentiation index of all the glasses analyzed show curvate (Fig. 11) instead of linear trends, and so magma mixing and equilibration are dismissed as the general process for magma evolution. Element variation diagrams (Fig. 11) suggest the following qualitative trend of fractional crystallization to be responsible for the magmatic evolution:

1. Decreasing $\mathrm{CaO}$ and $\mathrm{MgO}$ values indicate $\mathrm{Ca}-\mathrm{Mg}-(\mathrm{Fe}-)$ pyroxene fractionation after and perhaps during plagioclase fractionation at $\mathrm{MgO}>4$ and $\mathrm{Fe}-\mathrm{Ca}-(\mathrm{Mg}-)$ pyroxene fractionation at $\mathrm{MgO}<2 \%$.

2. $\mathrm{FeO}$ and $\mathrm{TiO}_{2}$ concentrations increase with decreasing $\mathrm{MgO}$ to about $4 \% \mathrm{MgO}$ and then rapidly decrease with decreasing $\mathrm{MgO}$, suggesting $\mathrm{Fe}$-Ti-oxide fractionation with continuing pyroxene fractionation.

3. $\mathrm{P}_{2} \mathrm{O}_{5}$ increases with decreasing $\mathrm{MgO}$. At intermediate $\mathrm{MgO}$ concentrations of about $2.5 \%, \mathrm{P}_{2} \mathrm{O}_{5}$ rapidly decreases because of apatite fractionation.

4. Initially, $\mathrm{Al}_{2} \mathrm{O}_{3}$ decreases slightly with decreasing $\mathrm{MgO}$ (plagioclase fractionation) and then increases until trachytic compositions with $\mathrm{MgO}$ at about $0.8 \%$ are reached. Decreasing $\mathrm{Al}_{2} \mathrm{O}_{3}$ indicates alkali feldspar fractionation.

5. $\mathrm{K}_{2} \mathrm{O}$ follows the $\mathrm{Al}_{2} \mathrm{O}_{3}$ trend at low $\mathrm{MgO}$ concentrations indicating $\mathrm{K}$-rich alkali feldspar (and perhaps some biotite) removal from the silicic magmas.

Figure 11 also shows two tentative trends (I and II) that are thought to follow the same differentiation mechanisms but show different starting compositions and/or P-T paths. Trend $\mathrm{I}$ is the line of evolution for the dominant high $\mathrm{Ti}(\mathrm{P}, \mathrm{K})$ basalt (T/E-MORB) to trachytic and alkali rhyolitic compositions, and trend $\mathrm{II}$ is the line of evolution for the very subordinate low $\mathrm{Ti}(\mathrm{K}, \mathrm{P})$ basalt $(\mathrm{N} / \mathrm{T}-\mathrm{MORB})$ to quartz trachytic to rhyolitic compositions. The pyroxene lines of evolution also show two parallel trends (Fig. 12). The Skaergaard pyroxene trend (Brown and Vincent, 1963) is inserted for comparison (" $\mathrm{S}$ " in the explanatory En-Wo-Fs triangle of Fig. 12). Trend I denotes the pyroxene evolution from calcic augites (low-Ti basalts) by way of ferro-salites to hedenbergites (trachytes to rhyolites). The parallel Trend II is the pyroxene evolution from high-Ti basalts (augites) to trachytes and alkali-rhyolites (ferroaugites/ferrosalites to ferric hedenbergites). Late-stage fractional crystallization of the Skaergaard intrusion led to progressive $\mathrm{Fe}$-enrichment in clinopyroxene compositions (Brown and Vincent, 1963). The parallel trends of pyroxene evolution (Fig. 12) from the basaltic to rhyolitic ash layers suggest the same fractional crystallization mechanisms for the Kerguelen magma reservoirs, except that the Kerguelen (layered) magma chambers explosively vented their material, whereas Skaergaard magmas remained a layered intrusion. The two different lines of pyroxene evolution seen in Figure 12 indicate at least two major pre-eruptive magmatic reservoir compositions that may depend on (1) source rock and partial melting differences and/or (2) depth and temperature differences.

Feldspar compositions also seem to follow two broad trends, which are (1) a more An-rich trend corresponding to glass composition Trend I, and (2) a less An-rich trend corresponding to glass composition Trend II. This model is based on glass and phenocryst compositions regardless of age 

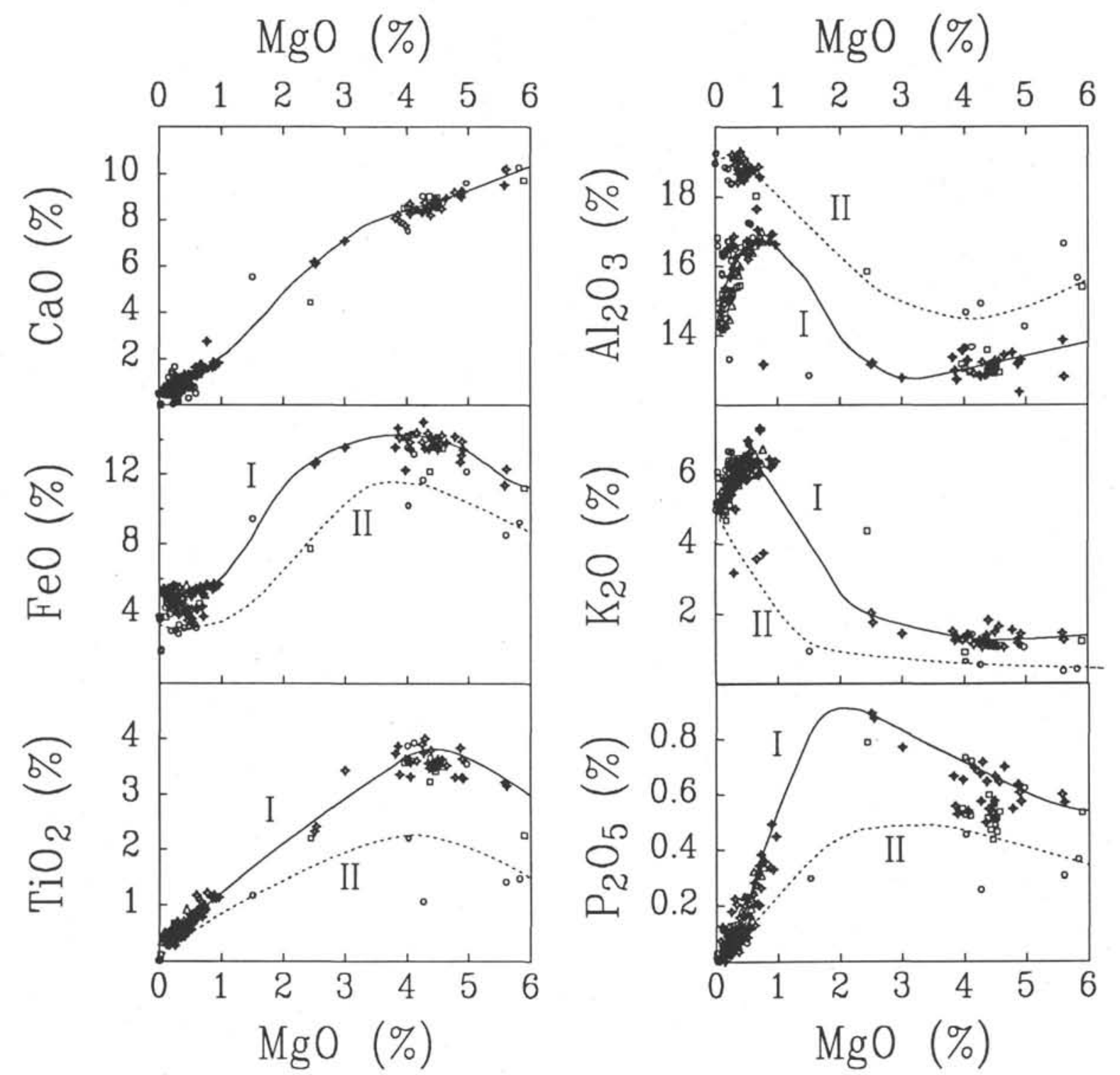

Figure 11. Major element concentrations vs. $\mathrm{MgO}$ (in wt\%) as a differentiation index and tentative evolutionary trends. Symbols as in Figure 3.

and site of deposition. The trends depict a general way in which Kerguelen magmas may have developed.

In summary, $\mathrm{Mg}$-Ca-(Fe-)-pyroxene and labradorite-plagioclase compositions dominate a (low-pressure?) basaltic magma fractional crystallization; intermediate compositions are controlled by Ti-magnetite and apatite fractionation, followed by $\mathrm{Fe}-\mathrm{Ca}-(\mathrm{Mg})$-pyroxene fractionation; and trachytic to rhyolitic compositions indicate final alkali feldspar fractionation. Fractionation of such accessory mineral phases such as biotite, alkali-amphibole, and sphene would not significantly change the major element trends but does severely affect incompatible trace element concentrations not considered here. The differentiation trends found within the glasses also occur within the pyroxene and plagioclase compositions and follow similar trends from the layered Skaergaard intrusion (e.g., Brown and Vincent, 1963) or from Thingmuli/Iceland (Carmichael, 1967).

However, the evolution of the basaltic to silicic shards by way of fractional crystallization is hampered by (1) the long duration of the explosive volcanism (>30 m.y.), (2) the absence of trace element and isotope data to assess consanguinity of the magmas, and (3) the lack of least-square modeling with the major element data set. In particular, the concept of partial melting of thickened oceanic crust may be another viable way to produce abundant silicic magmas.

\section{CONCLUSIONS}

\section{Pyroclastic Rocks (Ash Layers)}

Legs 119 and 120 recovered the first lateral (at least $900-\mathrm{km}$ lateral downwind distribution of fallout ashes) and vertical (Oligocene to Holocene) record of marine ash layers from the Kerguelen Plateau. Discrete and disseminated ash layers are a few centimeters thick, have median grain sizes (glass shards) of about $80 \pm 40 \mu \mathrm{m}$, and were a result of Plinian and/or co-ignimbrite ash clouds (silicic ashes). Basaltic ash layers with plate- and block-shaped shards and low vesicularity may have been spread by phreato-Plinian eruptions.

Fresh glasses from marine ash layers have basaltic (dominant high-Ti and very minor low-Ti T-MORB) and silicic 

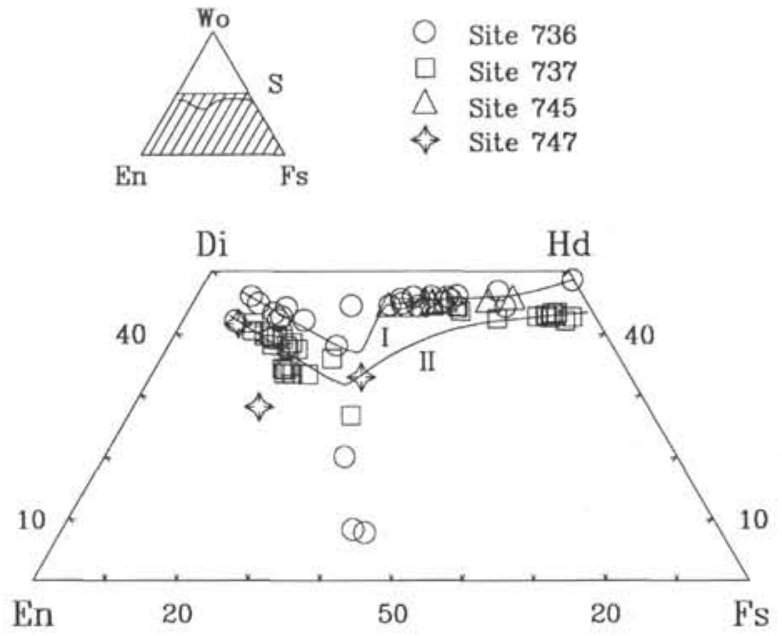

Figure 12. Clinopyroxene evolutionary trends in a Wo-En-Fs classification diagram (after Deer et al., 1977).

compositions (dominant high-K trachyte and rhyolite and very minor low-to-medium $\mathrm{K}$ rhyolites) with minor intermediate compositions. Glass compositions do not lie on a straight mixing line but suggest fractional crystallization to be the ruling process during magma evolution. Successive $\mathrm{Mg}$-CaFe-pyroxene, Ti-magnetite, and apatite fractionation with early and concomitant plagioclase and final K-rich alkali feldspar fractionation qualitatively explain the magma evolution path of the glasses from basaltic to rhyolitic by way of trachytic compositions. Plagioclase and clinopyroxene phenocryst compositions fit this general concept.

Sources of the widespread ash layers are eruptive centers on Kerguelen and (less likely) Heard islands, active since the Oligocene. The composition and evolution of the fallout ash layers and their sources in an oceanic-island setting (the Kerguelen Hotspot) can be compared with similar Tertiary, hotspot-induced, oceanic-island archipelagos with bimodal explosive volcanism (e.g., the Canary islands or Iceland and Jan Mayen Island; Schmincke, 1982; Bitschene et al., 1989b).

The ash layers mark the Oligocene onset of oceanic-islandtype explosive volcanism on the Northern Kerguelen Plateau and, thus, seamount/oceanic-island evolution to near-surface or emergent levels. Oceanic-island-type volcanism on the Northern Kerguelen Plateau occurred after the cessation of MORB volcanism on the Kerguelen Plateau, Broken Ridge, and Ninetyeast Ridge, and probably 5-10 m.y. after the final separation of the Broken Ridge from the Kerguelen Plateau at about 45-42 Ma (Munschy and Schlich, 1987).

\section{Epiclastic Rocks}

The epiclastic claystones from Site 750 have a T-MORB origin and indicate terrestrial weathering of an emergent Southern Kerguelen Plateau under warm, humid conditions in Cenomanian or earlier times. The epiclastic basal conglomerate of $\mathrm{Cr}$-rich glauconitic sediments from Site 748 marks the first major marine transgression into the Banzare Bank/Raggatt Basin of the Southern Kerguelen Plateau. The basal conglomerate has OIB compositions and resulted from erosion and reworking of oceanic-island-type alkali-basaltic volcanic edifices that developed in Turonian-Cenomanian(?) times above T-MORB-type Kerguelen Plateau basement and its weathering products (see "Site 750 Epiclastic Sediment" section, this chapter).

The epiclastic mass flow from Site 747 denotes a major tectonic event of Danian age on the Central Kerguelen Pla- teau, when T-MORB basement blocks and formerly lithified, marine volcaniclastic rocks were eroded and shed in three successive pulses into abyssal depths by massive turbidity currents. This tectonic and mass flow event predates the final Kerguelen Plateau-Broken Ridge separation (at 45-42 m.y.; Munschy and Schlich, 1987) by about $21 \mathrm{Ma}$, and may coincide with or immediately follow the termination of glauconitic epiclastic sedimentation in the Raggatt Basin on the Southern Kerguelen Plateau (Bitschene et al., this volume).

The volcaniclastic debris flow of Quaternary age from Site 736 belongs to the clastic apron of Kerguelen Island, which has shed its pyroclastic and epiclastic volcanogenic products at least $130 \mathrm{~km}$ into the sea away from their source regions on Kerguelen Island. The volcaniclastic debris flow(s) may indicate Quaternary uplift and renewed explosive volcanic activity on Kerguelen Island.

\section{ACKNOWLEDGMENTS}

$H$. Niephaus helped with thorough XRF analysis and $\mathrm{B}$. Schulz carried out $\mathrm{H}_{2} \mathrm{O}$ and $\mathrm{CO}_{2}$ determinations. H.-J. Bernhardt and W. Köhler Schnetger kindly assisted during microprobe analysis. This contribution greatly benefitted from the remarks of ODP reviewer $\mathrm{K}$. Rodolfo and an anonymous reviewer. We thank the "Deutsche Forschungsgemeinschaft" for funding this project under DFG grants Schm. 250/37-1 to -3 . This paper is dedicated to the memory of Lamar Hayes.

\section{REFERENCES}

Alibert, C., 1991. Mineralogy and geochemistry of a basalt from Site 738: implications for the tectonic history of the southernmost part of the Kerguelen Plateau. In Barron, J., Larsen, B., et al., Proc. ODP, Sci. Results, 119: College Station, TX (Ocean Drilling Program), 293-298.

Aubry, M.-P., and Berggren, W. A., 1989. Age of the upper volcaniclastic debris flow at Site 747: a special study. In Schlich, R., Wise, S. W., Jr., et al., Proc. ODP, Init. Repts., 120: College Station, TX (Ocean Drilling Program), 57-72.

Barron, J., Larsen, B., et al., 1989. Proc. ODP, Init. Repts., 119: College Station, TX (Ocean Drilling Program).

Bassias, Y., Davies, H. L., Leclaire, L., and Weis, D., 1987. Basaltic basement and sedimentary rocks from the southern sector of the Kerguelen-Heard Plateau: new data and their Meso-Cenozoic paleogeographic and geodynamic implication. Bull. Mus. Natl. Hist. Nat., Sect. C, 9:367-403.

Bitschene, P. R., Dehn, J., Mathis, J., Mehl, K., and Schmincke, H.-U., 1989a. Die vulkano-tektonische Entwicklung im Indischen Ozean (Kerguelen Plateau, Broken Ridge, Ninetyeast Ridge): Ergebnisse der ODP Legs 119, 120 und 121. Nachr. Dtsch. Geol. Ges., 41:12-13. (Abstract)

Bitschene, P. R., and Schmincke, H.-U., 1990. Fallout tephra layers: composition and significance. In Heling, D., Rothe, P., Förstner, U., and Stoffers, P. (Eds.), Sediments and Environmental Geochemistry: Berlin (Springer-Verlag), 48-82.

Bitschene, P. R., Schmincke, H.-U., and Viereck, L., 1989b. Cenozoic ash layers on the Vøring Plateau (ODP Leg 104). In Eldholm, O., Thiede, J., Taylor, E., et al., Proc. ODP, Sci. Results, 104: College Station, TX (Ocean Drilling Program), 357-366.

Brown, G. M., and Vincent, E. A., 1963. Pyroxenes from the late stages of fractionation of the Skaergaard intrusion, East Greenland. J. Petrol., 4:175-197.

Carmichael, I.S.E., 1967. The mineralogy of Thingmuli, a Tertiary volcano in eastern Iceland. Am. Mineral., 52:1815-1841.

Deer, W. A., Howie, R. A., and Zussman, J., 1977. An Introduction to the Rock Forming Minerals: New York (Longman).

Dosso, L., Vidal, P., Cantagrel, J. M., Lameyre, J., Marot, A., and Zimine, S., 1979. "Kerguelen: continental fragment or oceanic island?": petrology and isotopic geochemistry evidence. Earth Planet. Sci. Lett., 43:46-60.

Gautier, I., Verdier, O., and Weis, D., 1989. Isotopic systematics on Kerguelen differentiated alkaline volcanic rocks. Terra Abstr., 1:342. 
Hart, S. R., 1984. A large-scale isotope anomaly in the Southern Hemisphere mantle. Nature, 309:753-757.

LeMaitre, R. W., 1989. A Classification of Igneous Rocks and Glossary of Terms: Oxford (Blackwell Scientific Publications).

LeRoex, A. P., 1987. Source regions of mid-ocean ridge basalts: evidence for enrichment processes. In Menzies, M. A., and Hawkesworth, C. J. (Eds.), Mantle Metasomatism: London (Academic Press), 389-422.

McClelland, L., Simkin, T., Summers, M., Nielsen, E., and Stein, T. C., 1989. Global Volcanism, 1975-1985: Englewood Cliffs, NJ (Prentice Hall).

Mehl, K., Bitschene, P. R., Schmincke, H.-U., and Hertogen, J., 1991. Composition, alteration, and origin of the basement lavas and volcaniclastic rocks at Site 738, Southern Kerguelen Plateau. In Barron, J., Larsen, B., Baldauf, J., et al., Proc. ODP, Sci. Results, 119: College Station, TX (Ocean Drilling Program), 299-322.

Morimoto, N., 1988. Nomenclature of pyroxenes. Schweiz. Mineral. Petrogr. Mitt., 68:95-111.

Munschy, M., and Schlich, R., 1987. Structure and evolution of the Kerguelen-Heard Plateau (Indian Ocean) deduced from seismic stratigraphy studies. Mar. Geol., 76:131-152.
Schlich, R., Wise, S. W., Jr., et al., 1989. Proc. ODP, Init. Repts., 120: College Station, TX (Ocean Drilling Program).

Schmincke, H.-U., 1982. Volcanic and chemical evolution of the Canary Islands. In von Rad, U., Hinz, K., Sarnthein, M., and Seibold, E. (Eds.), Geology of the Northwest African Continental Margin: Berlin (Springer-Verlag), 273-306.

Storey, M., Saunders, A. D., Tarney, J., Gibson, I. L., Norry, M. J., Thirlwall, M. F., Leat, P., Thompson, R. N., and Menzies, M. A., 1989. Contamination of Indian Ocean asthenosphere by the Kerguelen-Heard mantle plume. Nature, 338:574-576.

Watkins, N. D., Gunn, B. M., Nougier, J., and Baksi, A. K., 1974. Kerguelen: continental fragment or oceanic island. Geol. Soc. Am. Bull., 85:201-212.

Yagi, K., and Onuma, K., 1967. The join $\mathrm{CaMgSi}_{2} \mathrm{O}_{6}-\mathrm{CaTiAl}_{2} \mathrm{O}_{6}$ and its bearing on the titanaugites. J. Fac. Sci. Hokkaido Univ., Ser. IV, 13:463-483.

Date of initial receipt: 27 February 1990

Date of acceptance: 8 November 1990

Ms 120B-132 